\title{
Relationships of Light to Enzyme and Sucrose Transformations in Sugarcane Treated with Paraquat $^{1}$
}

\author{
Alex G. Alexander and R. Montalvo-Zapata ${ }^{2}$
}

\section{INTRODUCTION}

The bipyridylium herbicides Paraquat ${ }^{3}$ and Diquat have attracted widespread interest as desiccants in the sugar industry $(21,25,31,37) .{ }^{5}$ They have shown promise in the drying of sugarcane at harvest time, also in flower control by destroying much of the green top at the period of floral initiation. Their effects on recoverable sucrose have been less encouraging. Studies in Puerto Rico revealed that sucrose is lost as a result of severe photosynthetic disruption while metabolic enzyme activity is retained at near-normal or even abnormally-high levels $(14,15)$. Field studies with Paraquat have shown moderate tonnage and sucrose losses (18). Nonetheless, a genuine need exists for chemicals having desiccative action in sugarcane.

The study of chemical mode of action, based on ultimate control of chemical effects, is a thoroughly sound investment both from academic and practical points of view. Investigations of controlled chemical action have begun in Puerto Rico. Alexander and Montalvo (16) achieved partial sucrose retention by treating cane with sodium meta-silicate one to several days prior to Paraquat or Diquat application. This compound is an effective inhibitor of cane hydrolytic and oxidative enzymes (12). Meta-silicate also has modified the growth-stimulatory and growth-decline phases of gibberellic acid activity in sugarcane (17). Significant improvements in controlling any chemical hinges upon new knowledge of its mode of action. For Paraquat and Diquat a promising point of departure is the investigation of light; particularly the roles of light in effecting shifts in enzyme behavior patterns.

Light is probably as essential for desiccant action in sugarcane as it is for other plant species. Studies of the broad bean, Vicid faba, have shown

1 This research was supported in part by a grant-in-aid from the Chevron Chemical Company, Ortho Division, Orlando, Florida.

2 Plant Physiologist and Assistant Chemist, respectively, Agricultural Experiment Station, Mayagüez Campus, University of Puerto Rico, Río Piedras, P.R.

3 1,1'-dimethyl-4,4-bipyridilium-bis-dimethyl sulfate, commercially known as Gramoxone.

'6,7-dihydrodipyrido (1,2-a:2',1'-c)-pyrazidilium salt, commercially known as Reglone.

Italic numbers in parentheses refer to Literature Cited, pp. 294-6. 
that Paraquat and Diquat are more toxic in light than in darkness (22), apparently as a result of a light-mediated reduction of the herbicides to free radical forms. Other forms of the $2: 3^{\prime}$-bipyridylium derivatives are non-toxic. Early work by Michaelis and Hill (44) showed that, unlike the majority of organic compounds reduced in a two-electron process, the reduction of $4: 4^{\prime}$-bipyridyl salts involved a delay in the addition of the second electron, so that there existed an intermediate reduction product having free-radical properties. The free radical has exceptional stability in the 4:4'-bipyridyl series which Boon (22) attributes to resonance.

Within a living plant the free radical might act in several ways. One possibility is the short-circuiting of energy generated during early stages of photosynthesis (22). Rather than NADP being reduced to NADPH, an essential step in a cycle leading to carbon fixation, the herbicide could be reduced and later reoxidized. Another possibility is the formation of toxic peroxide radicals, or hydrogen peroxide, following reoxidation of the free radical by molecular oxygen (24).

Although the production of free radicals from Paraquat and Diquat has never been confirmed in plants, Mees (4S) demonstrated that chlorophyll is essential for the typically rapid action of Diquat against green plant tissues. Funderburk and Lawrence (27) reported that Diquat and Paraquat inhibited photosynthesis in duckweed (Lemna minor L.). The photosynthetic phosphorylation of ATP is known to be stimulated by Paraquat $(98,39)$. Mees $(43)$ has further shown that oxygen, as well as light and chlorophyll, is needed to accomplish the rapid destruction of green tissues by Diquat and Paraquat. Vicia faba eventually dies, even in total darkness, following treatment with Diquat (22).

Fundamental work with Paraquat and Diquat had not been extended to sugarcane prior to the present series of studies in Puerto Rico. Alexander and Montalvo $(4,15)$ reported photosynthetic impairment by both herbicides during the conversion of triose phosphate to pentose phosphate, as evidenced by accumulations of free ribose in treated leaves. Hydrolytic and oxidative enzymes were stimulated or inhibited as a function of chemical concentration and time. Although no attempt was made at first to control light, it was observed that Paraquat and Diquat were more readily active when applied early on a clear day, rather than late in the day, or during cloudy weather.

The experiments reported herein employed variable illumination as an additional viewpoint from which to study Paraquat-enzyme and Paraquatsucrose relationships in sugarcane. There were three objectives: 1 , To clarify the dependence of Paraquat on light for its desiccative action; 2, to clarify the roles of light in abnormal enzyme behavior induced by Paraquat; and 3, to clarify the role of light in sucrose losses triggered by Paraquat. 


\section{EXPERIMENTAL PROCEDURE}

\section{GROWTH AND TREATMENT OF PLANT MATERIALS}

Two controlled-light experiments were conducted with immature sugarcane of the variety P.R. 980. Plants were grown in HCl-washed quartz sand contained in 2-gallon stoneware pots. One liter of a complete nutrient solution plus an equal amount of tap water was provided daily to each container of plants. ${ }^{6}$

For experiment 1, 14-week old plants were selected for uniformity and divided into two equal groups; half for retention in the greenhouse, the balance to be transferred to a darkened room. There were two Paraquat treatments within each group consisting of 0 and 0.05 percent solutions given as foliar sprays. The herbicide was dissolved in distilled water containing Tween 20 as wetting agent at the rate of $1.0 \mathrm{ml}$. per liter. The 0 Paraquat plants received Tween 20 in distilled water. All treatments were given at mid-afternoon, during a cloudy and relatively cool day, and all plants were sprayed until thoroughly wet. Those designated for dark treatment were quickly transferred to prerandomized positions in the room. About 5 minutes elapsed between initial spraying of plants and darkening of the chamber. Both darkened and illuminated plants were arranged in randomized block designs having two replicates of each treatment. The experiment was continued for 66 hours. Plant tissue samples were taken at $0,18,42$ and 66 hours.

Experiment 2 utilized 9-week old P.R. 980 plants grown in an identical manner. The 0 and 0.05 percent Paraquat levels were again employed with two groups of plants. One group remained in normal light and a second was darkened immediately after spraying. The dark treatment was continued for 72 hours, at which time the plants were returned to the greenhouse for a 72-hour reexposure to normal light. The remaining group was retained in the greenhouse for 144 hours. A randomized block design was used with two replicates of each treatment. Plant samples were harvested at $0,6,24,48,72,78,96,120$, and 144 hours.

The dark chamber was a modified storeroom and at best had only fair ventilation. Darkroom temperature remained several degrees higher at night than that of the greenhouse while day temperatures were roughly comparable. There was no humidity control. All plants continued to receive the standard nutrient and water allotments.

- Nutrient concentrations, expressed as milliequivalents per liter, were provided as follows: Nitrate, 10; phosphate, 6; potassium, 5; calcium, 3; magnesium, 2; and sulfate, 2 ; microelements, expressed as parts per million, were given as follows: Boron, 0.05 ; copper, 0.02; manganese, 0.50 ; zinc, 0.05 ; molybdenum, 0.01 ; and iron, 1.0 . 


\section{LABORATORY ANALYSES}

Leaves +1 to +4 and immature storage tissues were taken for sugar and enzyme analyses at each harvest period. These were quick-frozen in a mixture of dry ice and acetone and stored in a freezer. They were lyophilized and ground to pass a 60-mesh screen prior to extraction. Fresh weight for sheaths +1 to +4 were recorded at harvest and sheath moisture percentages were calculated after thorough drying in a forced-air oven.

Clarified water extracts of the tissue powder were analyzed for total ketose by the resorcinol method of Roe (48), and for sucrose by the modification of Cardini et al. (28). Fructose was estimated by substracting sucrose values from those of total ketose. Reducing sugars were determined by the method of Sumner (54).

Protein was precipitated from aqueous extracts with solid ammonium sulfate at pH 5.6. All samples were chilled for 30 minutes to increase protein yield. The 0-80 percent fraction was retained for enzyme assay. Precipitated protein was removed by centrifuge, dissolved in a minimum of distilled water, and dialyzed for 2 hours against two changes of water. Appropriate dilutions were prepared from the concentrates and all enzyme assays were completed within 48 hours of tissue extraction. Acid phosphatase and ATP-ase were assayed in accordance with procedures described earlier (4), as was invertase ( 5$)$, amylase $(6)$, polyphenol oxidase (7), and peroxidase (8). The microtechnique of Sutherland $e t$ al. (55) was used to measure both the water-soluble protein of tissue samples and the protein content of enzyme preparations. Enzyme action was computed as specific activity (activity units per mg. of protein).

Composited leaf samples were extracted with water and chromatographed on Whatman no. 1 filter paper, using the solvent mixture butanol-pyridinewater $(6: 4: 3, v / v)$ in one dimension. Extracts were concentrated by lyophilization prior to spotting on paper. Reference and unknown sugar spots were developed by the silver nitrate method of Dube and Nordin (26).

Biochemicals were purchased from the Nutritional Biochemicals Corporation, Cleveland, Ohio. Gramoxone (Paraquat) was supplied by local representatives of the Chevron Chemical Company, Ortho Division.

\section{RESULTS AND DISCUSSION}

\section{EXPERIMENT 1: CONTINUOUS DARKNESS VS. NATURAL LIGHT}

\section{Growth and Sugar Responses}

GRowTH.-None of the Paraquat-treated plants became desiccated or developed clear symptoms of any sort so long as they remained in the dark. 
Some small, faintly-reddish discolorations were visible in the foliage at 66 hours. Sugarcane given Paraquat and natural illumination developed injury symptoms which were very typical of those already described for both Paraquat and Diquat (15). However, really severe symptoms did not appear, apparently because of the cloudy conditions and short duration of the experiment. Sheath moisture content remained above 80 percent throughout the study.

sucrose.-Leaf sucrose values deteriorated markedly among all plants held in continuous darkness (table 1). There was no corresponding increase of sucrose in immature storage tissue; rather, a slight decline was recorded for control plants and a temporary loss at 18 hours for cane held in dark-

TABle 1.-Sucrose conlent of sugarcane sprayed wilh Paraqual and given variable illumination ${ }^{1}$

\begin{tabular}{|c|c|c|c|c|c|c|c|}
\hline \multirow{2}{*}{ Sucrose content for } & \multirow{2}{*}{ Light } & \multirow{2}{*}{$\begin{array}{c}\text { Paraquat } \\
\text { (percent } \\
\text { solution) }\end{array}$} & \multicolumn{4}{|c|}{ Hours after Paraquat treatment- } & \multirow{2}{*}{ Mean } \\
\hline & & & 0 & 18 & 42 & 66 & \\
\hline \multirow{4}{*}{$\begin{array}{l}\text { Leaves } \\
\text { (mg./g.) }\end{array}$} & \multirow[t]{2}{*}{ Natural } & 0 & 67.7 & 60.7 & 55.8 & 44.8 & 57.3 \\
\hline & & .05 & 62.8 & 41.3 & 14.9 & 10.3 & 32.3 \\
\hline & \multirow[t]{2}{*}{ Darkened } & 0 & 66.8 & 32.3 & 20.3 & 22.5 & 35.5 \\
\hline & & .05 & 60.3 & 27.6 & 19.1 & 10.8 & 29.5 \\
\hline \multirow{4}{*}{$\begin{array}{l}\text { Immature } \\
\text { storage tis- } \\
\text { sue (mg./g.) }\end{array}$} & \multirow{4}{*}{$\begin{array}{l}\text { Natural } \\
\text { Darkened }\end{array}$} & 0 & 142 & 145 & 102 & 94.9 & 96.0 \\
\hline & & .05 & 132 & 98.9 & 110 & 112 & 113 \\
\hline & & 0 & 125 & 84.9 & 115 & 119 & 111 \\
\hline & & .05 & 129 & 72.6 & 113 & 122 & 109 \\
\hline
\end{tabular}

1 Each figure represents the mean of 2 replicates.

ness. Paraquat caused very severe losses in plants receiving normal light (table 1, fig. 1,A). It is significant that in darkness the curve for leaf sucrose decline was similar for Paraquat-treated and control plants (fig. 1,B), and that both curves resemble that of Paraquat-treated plants held in light (fig. 1,A). This underscores active photosynthesis as the critical factor. It is implied that a rate-limiting light reaction is terminated equally well by darkness or Paraquat.

RIBOSE IN LEAVES.-A major photosynthesis blockage of the type reported earlier $(14,15,16)$ appears to have occurred at the site of phosphoribose isomerase action. Paper chromatography of leaf extracts revealed no ribose in untreated plants regardless of light exposure (fig. 2, A). Paraquat-treated foliage contained traces of ribose at 18 hours and greater amounts thereafter (fig. 2, B). Since the 5-carbon sugar did not appear in darkened plants, the suspected suppression of phosphoribose isomerase 


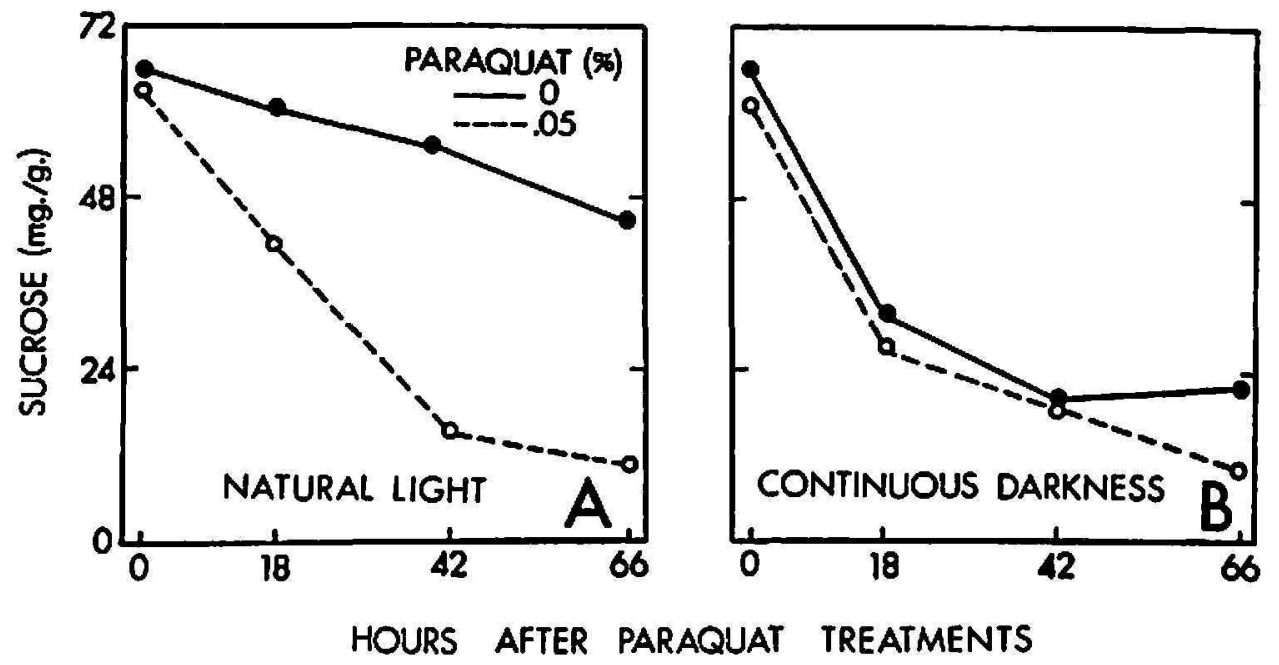

Frg. 1.-Effects of light and Paraquat on the leaf sucrose content of sugarcane: $A$, Sucrose decline in Paraquat-treated plants maintained in natural light; B, sucrose decline in all plants subjected to continuous darkness.

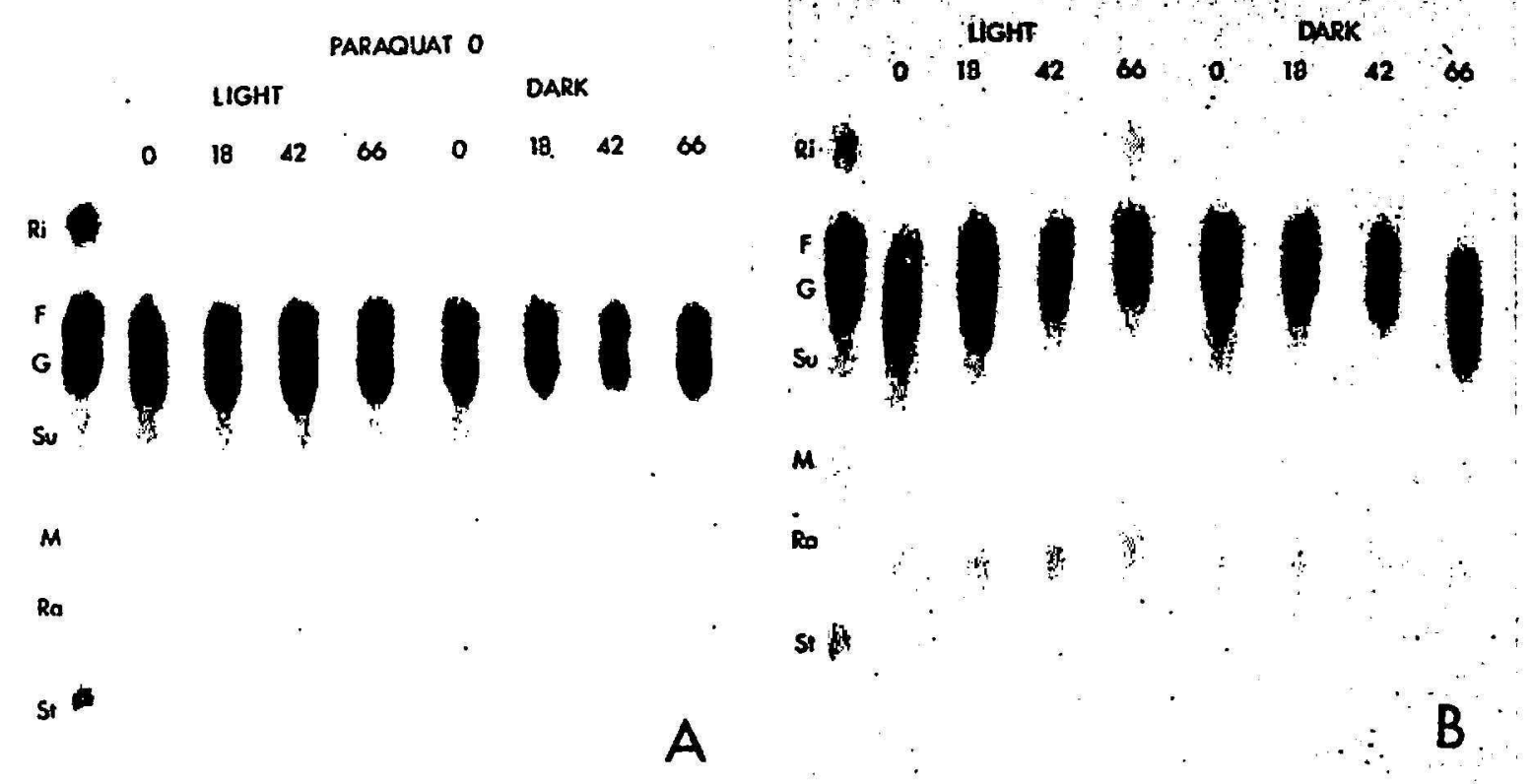

Fig. 2.-Effects of light and Paraquat on ribose content of sugarcane leaves: A, Absence of ribose in herbicide-free plants; B, appearance of ribose in illuminated plants given Paraquat, and failure of ribose to appear in darkened sugarcane. Letters at lef $t$ identify reference sugars as follows: $R i=$ ribose; $F=$ fructose; $G=$ glucose; $\mathrm{Su}=$ sucrose $\mathbf{M}=$ melezitose $; \mathbf{R} \mathbf{a}=$ raffinose $; \mathbf{S t}=$ stachyose.

must therefore require light. In this instance it is simpler to visualize a direct action by Paraquat, or by a peroxide formed via Paraquat-related reactions, rather than the gradual loss of enzyme-forming potential which would accompany energy-shunting reactions. 
From the standpoint of sucrose synthesis one might visualize a field of Paraquat-sprayed sugarcane as entering a prolonged period of more or less continuous night. From the grower's viewpoint this is a most important consideration, especially when the chemical is used for flower control some months before the crop is ready for harvest. One immediate question is whether sugarcane once "shocked" by Paraquat will recover with a more effective sugar-producing top than the original. We have little information relating the post-Paraquat and post-Diquat behavior, but past experience favors the opinion that a cane plant once injured becomes, in essence, a different plant upon recovery $(13,14)$.

With regard to preharvest desiccation, the present experiment verifies that sucrose production is finished for that crop within hours of Paraquat treatment. Sugar utilization does not stop. Metabolism control thus remains a significant challenge during the interim between desiccant application and grinding of the harvested stalks (16). Much sucrose might be saved simply by expediting the harvest of cane treated with Paraquat.

\section{Enzyme Responses}

In leaf tissues the enzymes amylase, phosphatase, and peroxidase each fluctuated during the 66-hour treatment period but none revealed new trends in response to light or Paraquat treatments (table 2). ATP-ase was an exception. This enzyme was greatly suppressed by Paraquat under normal light conditions, fig. 3, A, but the herbicide's effect was blocked by continuous darkness, fig. 3, B. This is another indication that the desiccant's action against enzymes is linked to light. Enzyme suppression by a chemical compound is surely conceivable in the absence of light. Failure to achieve consistent stimulation of amylase, or suppression of phosphatase and peroxidase, as observed previously $(14,15)$, is probably a manifestation of the generally poor performance of Paraquat during this experiment.

That Paraquat can be involved in the adenylic acid system of plants was shown by Jagendorf and Avron (39), and by Hill and Walker (38), when they demonstrated that Paraquat catalyzed the photosynthetic phosphorylation of ATP. Shropshire and Bergman (51), working with Phycomyces sporangiophores, observed major increases of ATP as a result of light saturation. No evidence of inhibitor destruction was presented, which in any event would be a function of excessive light rather than a light-curtailment such as the Paraquat action in cane increasingly appears to be. The ATP-ase suppression in cane is an extremely important factor since it reflects a lessened capacity of the plant to hydrolyze ATP, or conversely, a greater capacity to accumulate ATP. Whether or not this involves direct enzyme destruction or production of an inhibitor can only be speculated upon at this writing. 
TABLE 2.-Mean specific-activily values for leaf enzymes of sugarcane sprayed with Paraquat and given variable illumination ${ }^{1}$

\begin{tabular}{|c|c|c|c|c|c|c|c|}
\hline \multirow{2}{*}{ Enzyme } & \multirow{2}{*}{ Illumination } & \multirow{2}{*}{$\begin{array}{c}\text { Paraquat } \\
\text { (percent } \\
\text { solution) }\end{array}$} & \multicolumn{4}{|c|}{ Hours after Paraquat treatment- } & \multirow{2}{*}{ Mean } \\
\hline & & & 0 & 18 & 42 & 66 & \\
\hline \multirow[t]{4}{*}{ Phosphatase } & \multirow[t]{2}{*}{ Natural } & 0 & 21.2 & 25.4 & 17.3 & 15.8 & 19.9 \\
\hline & & .05 & 18.1 & 15.9 & 14.1 & 14.3 & 15.6 \\
\hline & \multirow[t]{2}{*}{ Darkened } & 0 & 20.2 & 15.5 & 16.1 & 16.1 & 17.0 \\
\hline & & .05 & 18.6 & 15.3 & 12.6 & 13.9 & 15.1 \\
\hline \multirow[t]{4}{*}{ ATP-ase } & \multirow[t]{2}{*}{ Natural } & 0 & 25.0 & 28.0 & 21.8 & 20.0 & 23.7 \\
\hline & & .05 & 22.4 & 15.0 & 5.8 & 4.9 & 12.0 \\
\hline & \multirow[t]{2}{*}{ Darkened } & 0 & 27.1 & 21.2 & 19.1 & 17.9 & 21.3 \\
\hline & & .05 & 22.3 & 22.6 & 16.2 & 18.4 & 19.9 \\
\hline \multirow[t]{4}{*}{ Amylase } & \multirow[t]{2}{*}{ Natural } & 0 & 86.8 & 77.4 & 68.9 & 49.2 & 70.5 \\
\hline & & .05 & 67.0 & 80.9 & 53.2 & 62.2 & 65.9 \\
\hline & \multirow[t]{2}{*}{ Darkened } & $\mathbf{0}$ & 58.8 & 53.4 & 64.3 & 75 & 62.8 \\
\hline & & .05 & 48.5 & 35.9 & 62.8 & 70.2 & 54.3 \\
\hline \multirow[t]{4}{*}{ Peroxidase } & \multirow[t]{2}{*}{ Natural } & 0 & 130 & 165 & 138 & 152 & 146 \\
\hline & & .05 & 149 & 134 & 123 & 131 & 134 \\
\hline & \multirow{2}{*}{ Darkened } & 0 & 173 & 158 & 156 & 197 & 171 \\
\hline & & .05 & 151 & 169 & 149 & 130 & 150 \\
\hline
\end{tabular}

${ }^{1}$ Each figure represents the mean of 2 replicates.

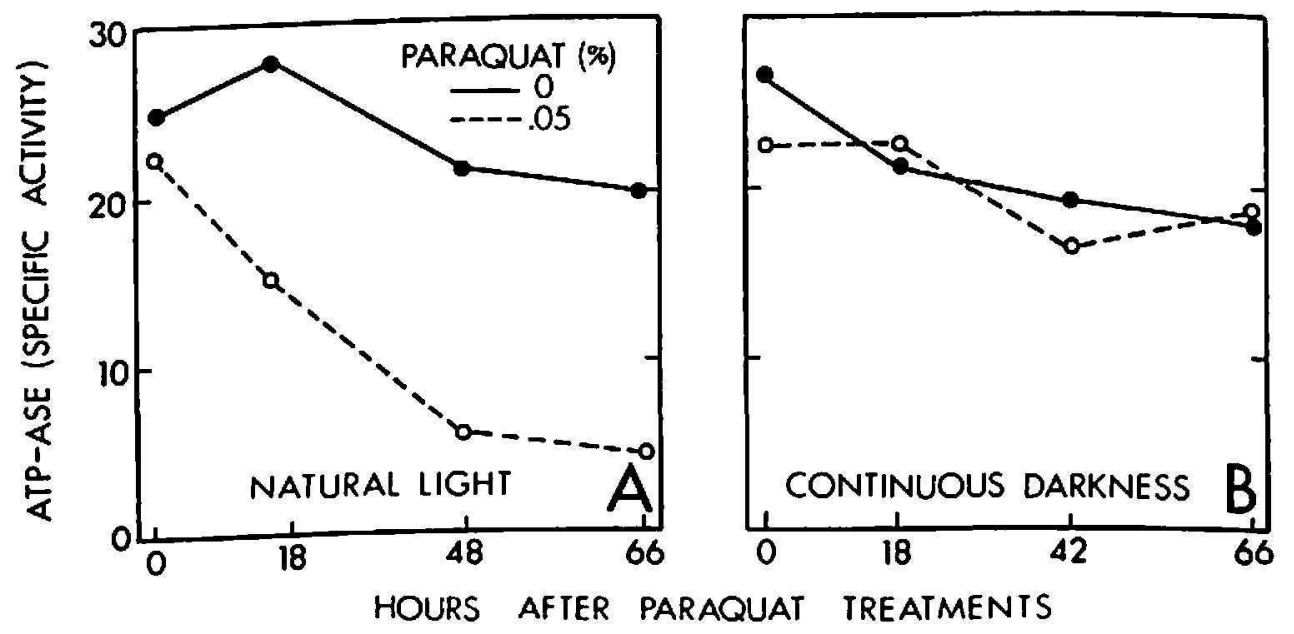

Fig. 3.-Effects of Paraquat on leaf ATP-ase of sugarcane exposed to variable light: A, ATP-ase decline in normal daylight; B, removal of Paraquat inhibition by darkness. 
With the exception of invertase, enzymes in immature storage tissue likewise failed to change notably in response to light or Paraquat (table 3). Invertase action clearly subsided in the dark for both Paraquat-treated and non-treated plants. Paraquat effectively inhibited invertase activity during earlier experiments conducted in natural light.

TABLE 3.-Mean specific-activity values for immalure storage tissue enzymes of sugarcane sprayed with Paraquat and given variable illumination ${ }^{1}$

\begin{tabular}{|c|c|c|c|c|c|c|c|}
\hline \multirow{2}{*}{ Enzyme } & \multirow{2}{*}{ Illumination } & \multirow{2}{*}{$\begin{array}{c}\text { Paraquat } \\
\text { (percent } \\
\text { solution) }\end{array}$} & \multicolumn{4}{|c|}{ Hours after Paraquat treatment- } & \multirow{2}{*}{ Mean } \\
\hline & & & 0 & 18 & 42 & 66 & \\
\hline Phosphatase & $\begin{array}{l}\text { Natural } \\
\text { Darkened }\end{array}$ & $\begin{array}{l}0^{0} .05 \\
0.05\end{array}$ & $\begin{array}{l}22.7 \\
27.4 \\
28.7 \\
23.3\end{array}$ & $\begin{array}{l}21.8 \\
23.6 \\
25.9 \\
24.5\end{array}$ & $\begin{array}{l}27.2 \\
24.8 \\
25.2 \\
24.5\end{array}$ & $\begin{array}{l}24.3 \\
23.4 \\
21.0 \\
26.2\end{array}$ & $\begin{array}{l}24.0 \\
24.8 \\
25.2 \\
24.6\end{array}$ \\
\hline ATP-ase & $\begin{array}{l}\text { Natural } \\
\text { Darkened }\end{array}$ & $\begin{array}{l}0^{0} .05 \\
0 \\
.05\end{array}$ & $\begin{array}{l}24.9 \\
25.0 \\
25.4 \\
18.6\end{array}$ & $\begin{array}{l}22.3 \\
23.9 \\
25.9 \\
20.7\end{array}$ & $\begin{array}{l}26.5 \\
20.7 \\
23.9 \\
22.7\end{array}$ & $\begin{array}{l}22.6 \\
19.6 \\
21.0 \\
22.8\end{array}$ & $\begin{array}{l}24.1 \\
22.3 \\
24.1 \\
21.2\end{array}$ \\
\hline Amylase & $\begin{array}{l}\text { Natural } \\
\text { Darkened }\end{array}$ & $\begin{array}{l}0 \\
.05 \\
0 \\
.05\end{array}$ & $\begin{array}{l}57.9 \\
71.1 \\
53.2 \\
68.6\end{array}$ & $\begin{array}{l}63.4 \\
57.9 \\
39.3 \\
47.2\end{array}$ & $\begin{array}{l}60.4 \\
65.8 \\
46.1 \\
66.4\end{array}$ & $\begin{array}{l}69.9 \\
80.4 \\
58.1 \\
71.1\end{array}$ & $\begin{array}{l}62.9 \\
68.8 \\
49.2 \\
63.3\end{array}$ \\
\hline Invertase & $\begin{array}{l}\text { Natural } \\
\text { Darkened }\end{array}$ & $\begin{array}{l}0 \\
0^{.05} \\
.05\end{array}$ & $\begin{array}{r}9.4 \\
8.5 \\
10.6 \\
9.6\end{array}$ & $\begin{array}{r}7.1 \\
6.8 \\
10.3 \\
9.3\end{array}$ & $\begin{array}{l}9.2 \\
8.8 \\
5.0 \\
5.3\end{array}$ & $\begin{array}{l}7.8 \\
6.1 \\
3.2 \\
3.8\end{array}$ & $\begin{array}{l}8.4 \\
7.6 \\
7.3 \\
6.5\end{array}$ \\
\hline Peroxidase & $\begin{array}{l}\text { Natural } \\
\text { Darkened }\end{array}$ & $\begin{array}{l}0 \\
0^{.05} \\
.05\end{array}$ & $\begin{array}{l}46.7 \\
33.7 \\
40.9 \\
35.3\end{array}$ & $\begin{array}{l}45.6 \\
32.8 \\
39.2 \\
32.8\end{array}$ & $\begin{array}{l}48.2 \\
38.0 \\
44.7 \\
35.9\end{array}$ & $\begin{array}{l}42.3 \\
40.8 \\
42.4 \\
44.0\end{array}$ & $\begin{array}{l}45.7 \\
36.3 \\
41.8 \\
37.0\end{array}$ \\
\hline
\end{tabular}

1 Each figure represents the mean of 2 replicates.

While evidence of light involvement in plant invertase synthesis has been published, definite proof of light essentiality has been difficult to come by. Kaufman et al. (40) incubated Avena stem segments in the dark to obtain nil invertase synthesis and then demonstrated a stimulatory effect of GA on invertase activity. The GA stimulation was closely correlated with rate of tissue elongation. Invertase activity has also been correlated with growth rate in lentil epicotyls (50), and sugarcane (36). Kaufman and coworkers then employed inhibitors of protein and RNA synthesis to 
support their thesis that GA stimulated synthesis of Avena protein rather than simply reactivating existing invertase made latent by darkness.

In Australia, where cane experiences definite seasonal variations, invertase activity has reportedly varied by several orders of magnitude on a seasonal basis. Slack (52) observed diurnal fluctuations of invertase activity for cane grown in the field and in controlled-climate facilities. No invertase response was obtained by treatment with low-intensity red or far-red light during dark periods. Workers in Australia favor invertase synthesis control by a dual system of hormone regulation and suppression by feedback of inversion products $(30,49,52)$.

Working with potato invertase, Pressey $(45,46)$ isolated and partially purified invertase inhibitors from red beets, sugar beets, and sweet potatoes. Pressey surmised that the invertase activity increases which occur in aging beet slices, and are inhibited by fluorophenylalanine, can be interpreted in terms of inhibitor destruction rather than strictly de novo synthesis (46). Evidence of cane invertase inhibitors has been encountered during gel filtration studies of immature storage tissue preparations (42). The possibility of a light-destroyed inhibitor complex in cane, one whose natural restraints are removed by Paraquat, cannot be discounted.

\section{EXPERIMENT 2: DARKNESS PLUS LIGHT VS. NATURAL ILLUMINATION}

\section{Growth Responses}

The second experiment was initiated at 9:00 a.m. on a sunny day and extended 144 hours, more than twice the duration of the first study. Paraquat injury symptoms were appearing by sundown of the first day, some $8 \frac{1}{2}$ hours after Paraquat application. By 72 hours Paraquat had severely desiccated most of the green-leaf area of plants remaining under natural illumination. Sheath-moisture values were clearly dropping after 48 hours (fig. 4, A, table 4). At 96 hours the first signs of a healthy, newly-emerging green spindle were recorded.

Plants removed from darkness at 72 hours appeared quite normal at first glance. Newly-emerging spindles were very slightly yellowed. Paraquat-treated cane revealed faint traces of reddish discoloration in the foliage. Quite significantly, these plants quickly began to wilt in the sunlight and by nightfall appeared to have progressed through several days of Paraquat activity. However, if sheath moisture values are used as a guideline, we must conclude that darkness effectively prevented severe desiccation throughout the 144-hour period (fig. 4, B).

LEAF RIBOsE.-The Paraquat-treated plants exposed to natural light produced traces of ribose within 6 hours (fig. 5). The chromatogram in figure 5 also illustrated the loss of fructose and glucose, further evidence 
of slackened photosynthesis as a consequence of Paraquat activity. Untreated plants lost a great deal of fructose, glucose, and sucrose in the dark (fig. 6, A). Each of the three sugars quickly reappeared upon reexposure to sunlight. Treated sugarcane did not produce ribose in the dark, but it did appear within 6 hours after reillumination (fig. 6, B). This suggests

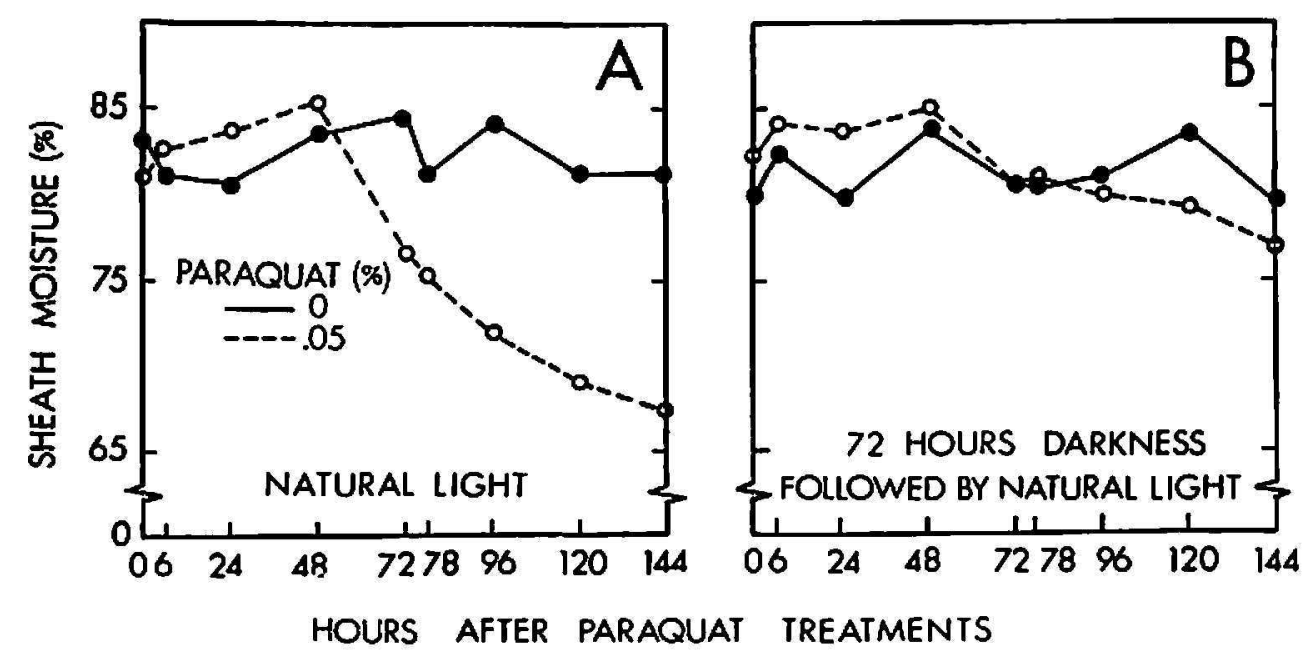

Frg. 4.- Sheath moisture percentages for sugarcane sprayed with Paraquat and subjected to variable illumination.

TABLE 4.-Sheath moisture percenlage for immalure sugarcane sprayed with Paraquat and subjected to variable light exposure. ${ }^{1}$ The "dark plus light" treatments consisted of continuous darkness for 72 hours after Paraquat application, followed by 72 hours of normal illumination

\begin{tabular}{|c|c|c|c|c|c|c|c|c|c|c|c|}
\hline \multirow{2}{*}{$\begin{array}{c}\text { Light } \\
\text { treatment }\end{array}$} & \multirow{2}{*}{$\begin{array}{l}\text { Paraquat } \\
\text { (percent } \\
\text { solution) }\end{array}$} & \multicolumn{9}{|c|}{ Hours after Paraquat treatment- } & \multirow{2}{*}{ Mean } \\
\hline & & 0 & 6 & 24 & 48 & 72 & 78 & 96 & 120 & 144 & \\
\hline \multirow[t]{2}{*}{ Natural } & 0 & 83.3 & 81.1 & 80.8 & 83.6 & 84.8 & 81.2 & 84.6 & 81.1 & 81.5 & 82.4 \\
\hline & .05 & 81.0 & 82.9 & 83.8 & 85.2 & 76.8 & 75.3 & 72.0 & 69.1 & 67.5 & 76.8 \\
\hline Dark + & 0 & 80.0 & 82.5 & 79.7 & 84.0 & 80.4 & 80.3 & 81.0 & 83.8 & 79.4 & 81.2 \\
\hline light & .05 & 82.2 & 84.4 & 83.8 & 85.0 & 80.4 & 80.8 & 79.9 & 79.1 & 76.9 & 81.4 \\
\hline
\end{tabular}

1 Each figure represents the mean of 2 replicates. Four uniform plants were harvested from each replicate and moisture percentages were determined for sheaths +1 to +4 .

that light is required for isomerase inhibition, that no dark reaction is involved, and that darkness can delay but not prevent ultimate inhibition. It is very significant, however, to note that while darkness did not prevent the eventual isomerase suppression, it did permit the recovery of fructose and glucose production (fig. 6, B). Some photosynthetic activity thus was apparently recovered. No such recovery was observed earlier in the absence 
of dark treatments $(1 / 4,15)$. The obvious implication here is that because of the dark period, during which cane was alerted to the toxic potential of Paraquat, a means was found to produce ribulose-5-phosphate without employing the vulnerable phosphoribose isomerase reaction with ribose-5phosphate (19). A possible method was the production of xylulose-5-phosphate from thiamine pyrophosphate-glycolaldehyde plus glyceraldehyde phosphate, as described by Bassham (20, pp. 888-89), followed by the action of ribulose phosphate-xylulose phosphate isomerase to yield ribulose-

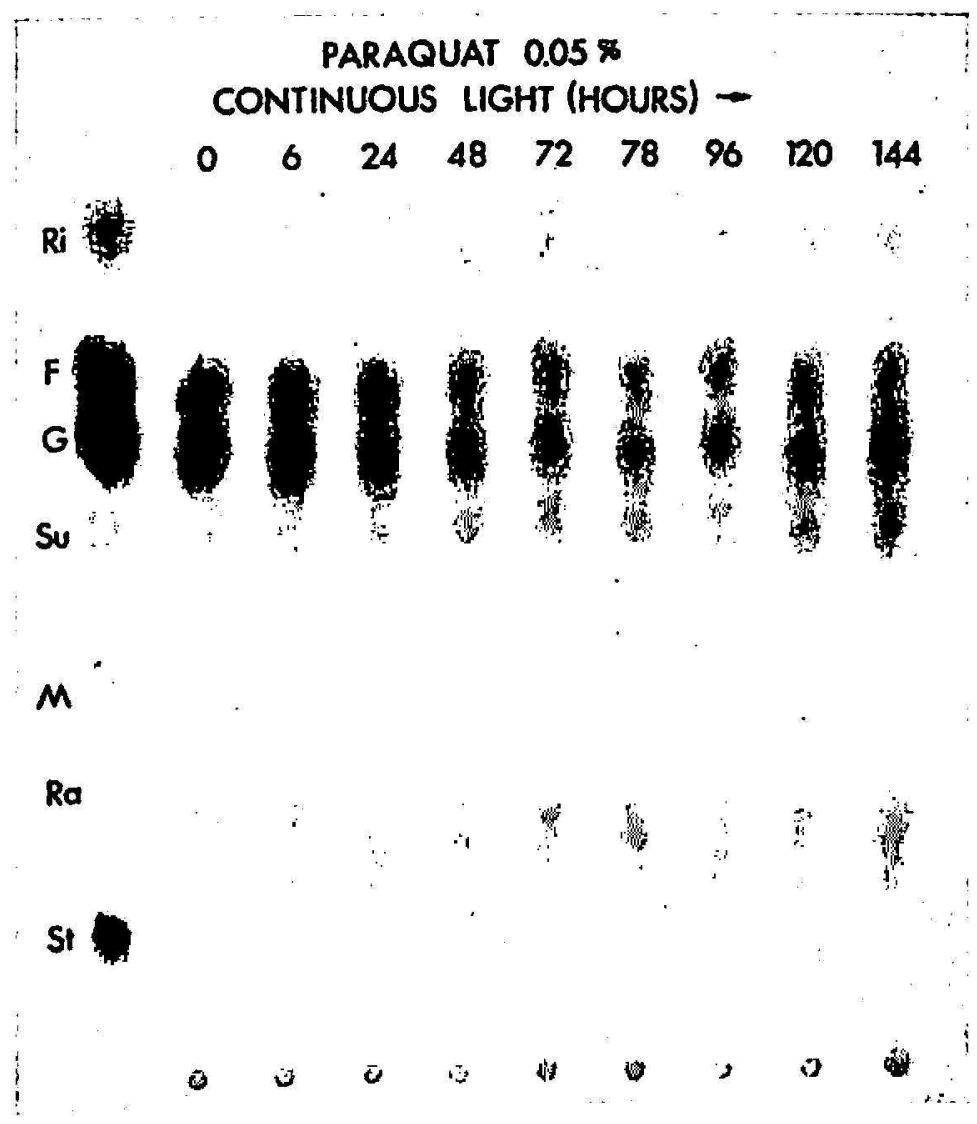

Fig. 5.-Ribose formation in leaves of sugarcane treated with Paraquat and maintained under normal light. Letters at left identify reference sugars as follows: Ri = ribose $\mathbf{F}=$ fructose $; \mathrm{G}=$ glucose $\mathrm{Su}=$ sucrose $\mathrm{M}=$ melezitose; $\mathbf{R a}_{\mathbf{a}}=$ raffinose; $\mathrm{St}=$ stachyose.

5-phosphate. Thus we have circumstantial evidence for two means of ribulose-5-phosphate production by cane, mechanisms elucidated in Chlorella pryenoidosa (20, pp. 583-90, 58).

Another important observation was the failure of leaf sucrose content to increase along with fructose and glucose (fig. 6, B, table 5). There was adequate time for sucrose to appear. Figure $6, \mathrm{~A}$ illustrates sucrose reappearing in sunlight just as quickly as did the two reducing sugars. The herbicide may possibly interfere with production of sucrose precursors 
such as UDPG or glucose-1-phosphate, or it could suppress activity of enzymes directly involved in uniting fructose and glucose (sucrose synthetase, UDPG-fructose transglycosylase, sucrose phosphorylase).

\section{Sucrose Responses}

On the basis of earlier experience with Paraquat we expected severe leaf sucrose losses and this did in fact occur (fig. 7, A). Sucrose values for plants under natural light fluctuated considerably even in the absence of

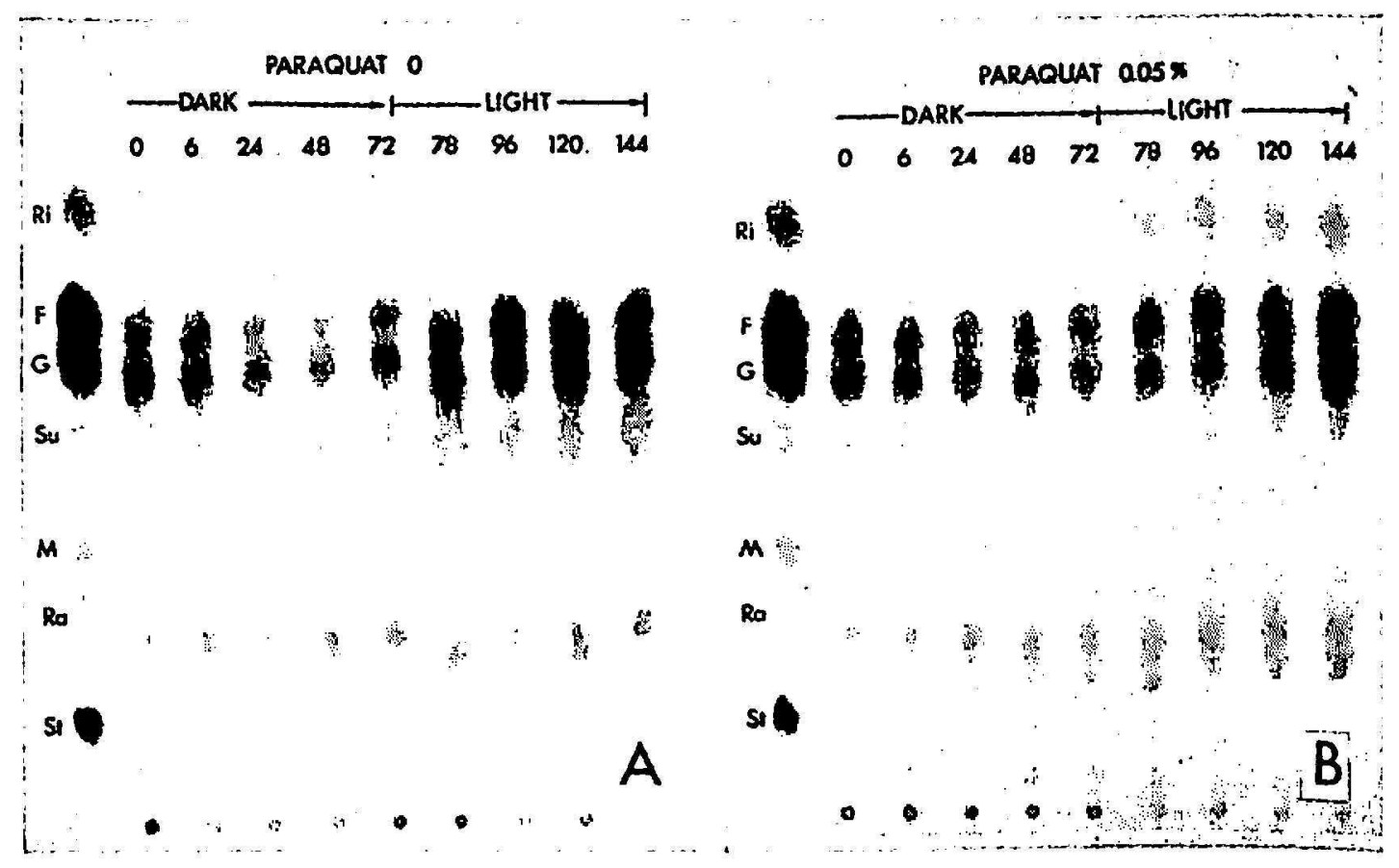

Fig. 6.-Effects of Paraquat on leaf sugar constituents of sugarcane given variable illumination: A, Sucrose and reducing sugar decline in Paraquat-free plants darkened for 72 hours; recovery of the 3 sugars after reillumination at 72 hours. B, Failure of ribose to appear in Paraquat-treated leaves kept in darkness, and appearance of ribose upon reillumination. Also evident is the recovery of fructose and glucose, but no sucrose, after transfer of the plants to normal light.

Paraquat, but those sprayed with Paraquat lost all except a trace of sucrose by 48 hours. All of the darkened plants lost sucrose regardless of chemical treatment (fig. 7, B). As was true of experiment 1, the sucrose decline curves are almost identical for the 0.05 percent Paraquat and darkness treatments. This supports the concept of chemical interference with active photosynthesis and that, from a sucrose-synthesis standpoint, Paraquattreated plants are, in effect, experiencing continuous night.

A very striking increase of leaf sucrose was detected 6 hours after reexposure to sunlight (fig. 7, B, table 5). The reader can observe the sugars involved in this remarkable change by comparing the 72- and 78-hour 
TABLE 5.-Sucrose content of Paraqual-lreated sugarcane darkened for 72 hours prior to receiving nalural light ${ }^{1}$

\begin{tabular}{|c|c|c|c|c|c|c|c|c|c|c|c|}
\hline \multirow{3}{*}{ Sucrose content for- } & \multirow{3}{*}{$\begin{array}{c}\text { Paraquat } \\
\text { (percent } \\
\text { solution) }\end{array}$} & \multicolumn{9}{|c|}{ Hours after Paraquat treatment- } & \multirow{3}{*}{ Mean } \\
\hline & & \multicolumn{5}{|c|}{ In total darkness } & \multicolumn{4}{|c|}{ In normal light } & \\
\hline & & 0 & 6 & 24 & 48 & 72 & 78 & 96 & 120 & 144 & \\
\hline \multirow[t]{2}{*}{ Lenves (mg./g.) } & $\begin{array}{l}0 \\
.05\end{array}$ & $\begin{array}{l}28.9 \\
27.6\end{array}$ & $\begin{array}{l}30.9 \\
18.1\end{array}$ & $\begin{array}{r}26.9 \\
6.7\end{array}$ & $\begin{array}{r}25.2 \\
1.4\end{array}$ & $\begin{array}{r}38.8 \\
1.4\end{array}$ & $\begin{array}{r}36.1 \\
1.6\end{array}$ & $\begin{array}{r}35.8 \\
1.2\end{array}$ & $\begin{array}{r}22.7 \\
1.2\end{array}$ & $\begin{array}{r}30.4 \\
1.4\end{array}$ & $\begin{array}{r}31.3 \\
6.7\end{array}$ \\
\hline & Mean & 28.3 & 27.5 & 16.8 & 13.3 & 20.1 & 18.9 & 18.5 & 11.9 & 15.9 & \\
\hline \multirow[t]{2}{*}{$\begin{array}{l}\text { Immature storage } \\
\text { tissue (mg./g.) }\end{array}$} & $\begin{array}{l}0 \\
.05\end{array}$ & $\begin{array}{l}22.5 \\
27.9\end{array}$ & $\begin{array}{l}37.2 \\
33.9\end{array}$ & $\begin{array}{l}38.6 \\
32.7\end{array}$ & $\begin{array}{l}52.5 \\
61.8\end{array}$ & $\begin{array}{l}62.1 \\
60.3\end{array}$ & $\begin{array}{l}122 \\
60.6\end{array}$ & $\begin{array}{l}45.0 \\
60.0\end{array}$ & $\begin{array}{l}59.0 \\
58.2\end{array}$ & $\begin{array}{l}42.9 \\
61.5\end{array}$ & $\begin{array}{l}53.5 \\
50.8\end{array}$ \\
\hline & Mean & 25.2 & 35.6 & 35.7 & 57.2 & 61.2 & 91.3 & 52.5 & 58.6 & 52.2 & \\
\hline
\end{tabular}

1 Each figure represents the mean of 2 replicates. 
samples under "Paraquat 0" (fig. 6, A). The sucrose-forming mechanisms clearly remained viable throughout the 72 hours of darkness, so long as Paraquat was withheld. Plants that received the desiccant completely failed to respond even though they were still green and outwardly normal in appearance when removed to light.

One might attribute the high 78-hour value to a delay in sucrose transport from the leaves. Rapid movement would not begin, supposedly, until around 80 hours. The 96-hour samples taken the following morning do show leaf sucrose at a near-normal level (fig. 7, B). Other interpretations can be made for the high sucrose values: 1 , The carbohydrate-free cells

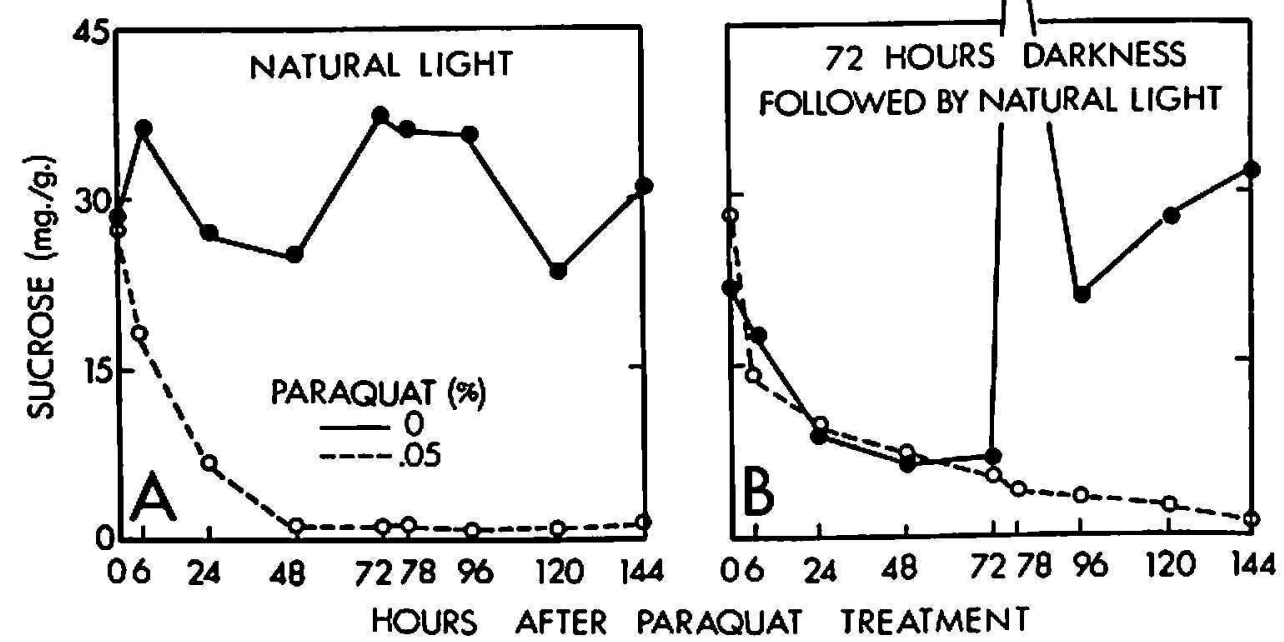

Fig. 7.- Leaf sucrose changes in Paraquat-treated sugarcane given variable light exposure: A, Sucrose decline under natural light; B, sucrose decline in all sugarcane darkened for 72 hours, followed by sucrose recovery in reilluminated, Paraquat-free plants.

and chloroplasts and unobstructed channels of transport might permit the darkness-free mechanisms to approach their theoretical potential; 2 , the mechanisms themselves may have been improved during the unnatural period of inactivity. One could investigate synthetic efficiency with a continuous and precisely-controlled light source, plus a cell-free system. A living plant of even leaf dises could not be used since sugar transport always would become a limiting factor regardless of synthesizing potential.

The concept of sucrose transport has been explored more thoroughly perhaps than any other physiological problem of sugarcane. More than two decades ago Loomis (41) suggested that accumulated end products might become limiting factors in photosynthesis. Hartt et al. (32) demonstrated 
that sucrose is the principal compound translocated in sugarcane. Movement was traced downward through leaf and leaf sheath to the stalk, then to the center of the stalk and downward-the bulk moving toward the base and roots, while lesser amounts enter a system moving up toward the growing point and spindle. The latter tissues are reached by some sucrose before any arrives at the roots. Most of the daily sucrose product is stored in the stem; primarily in ripening internodes but also in mature internodes. Hartt reported that the leaf blade can continue a maximum photosynthetic rate for about 2 hours (34), and concluded that sucrose accumulation in

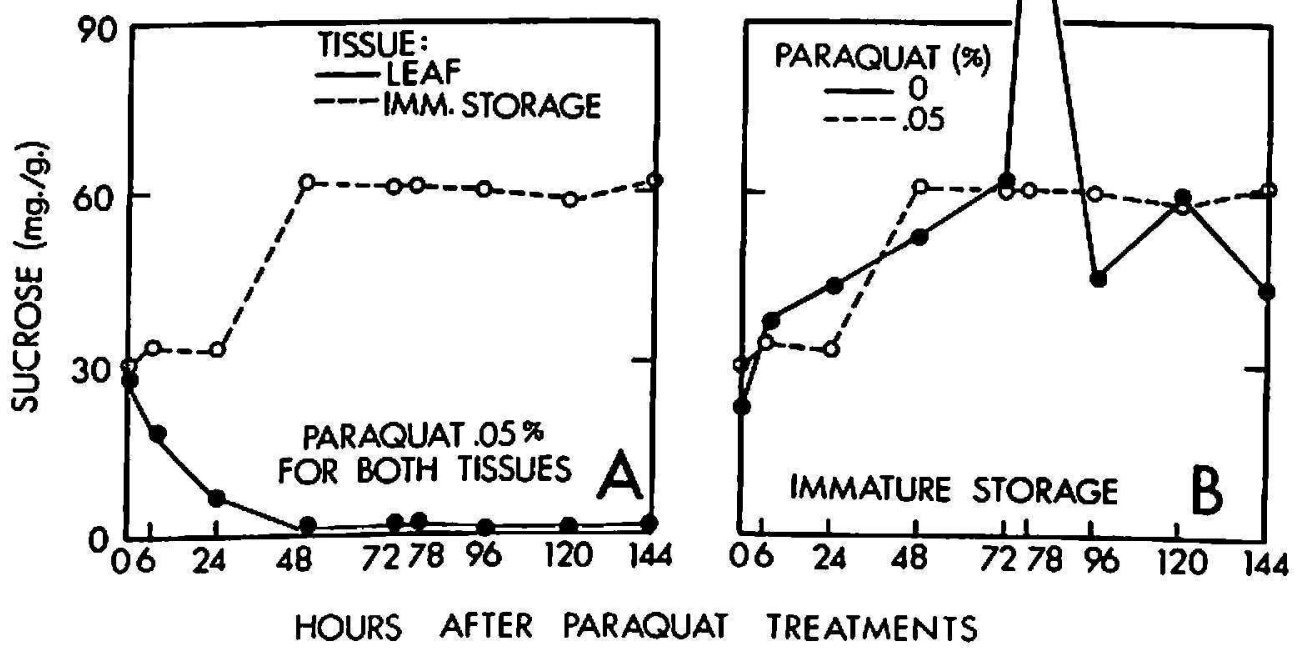

Fig. 8.-Effects of Paraquat on sucrose content of sugarcane exposed to variable light. All plants were darkened for 72 hours and subsequently moved into natural light.

leaves during the day can inhibit photosynthesis. Other factors such as wind injury and leaf moisture content also were evaluated (83). More recent studies by Hartt have stressed the importance of water in photosynthate transport (35).

Sucrose values for immature storage tissue varied greatly in response to Paraquat and light (fig. 8, table 5). As illustrated by figure 8, A, darkness induced losses of leaf sucrose were accompanied by a general sucrose rise in immature storage tissue. Sucrose transport thus appears to have continued for about 48 hours after photosynthesis ceased. After 48 hours an unusual consistency of sucrose values was recorded for both tissues (fig. $8, \mathrm{~A})$. However, this was not due simply to a closing off of photosynthesis, but rather involved a specific Paraquat effect. This is illustrated by figure $8, \mathrm{~B}$, in which little consistency and broad sucrose fluctuation are shown for 
plants not sprayed with Paraquat. A comparison of Paraquat and nonParaquat treatments for immature storage tissue does in fact reveal a strikingly high sucrose value at 78 hours for control plants. This corresponds to the high leaf sucrose value discussed above and presented in figure $7, \mathrm{~B}$. Two conclusions can thus be drawn: 1, Paraquat does not immediately interfere with active sucrose transport per se, 2 , it appears to do so through secondary reactions. If we again consider sheath moisture an adequate guideline the virtual freezing of sucrose values from 48 hours onward could be attributed to water stress, but only in those plants given normal illumination (fig. 3, A and B). Plants darkened for 72 hours did not approach miosture stress until the close of the study. Nor would closing off the sucrose supply from leaves guarantee constancy in immature storage tissues since the latter remain alive, turgid, and actively participating in the plant's recovery. Hartt et al. (32) state that sucrose reaching "young stems" and certain other tissues is converted to compounds needed for growth of cell walls and protoplasm.

A possible explanation for the Paraquat stabilization of sucrose might be the herbicide's inhibition of invertase activity. Earlier studies by Glasziou (29) revealed that immature cane tissues were 8 to 10 times more permeable to reducing sugars than to sucrose. To account for sucrose accumulation beyond a permeability barrier, Glasziou proposed a mechanism entailing a carrier situated in the barrier. This barrier, believed to be the tonoplast membrane, separates the outer and inner space of the tissue. Supposedly it is transcended by aid of the carrier and by action of a specific invertase which temporarily reverts the sucrose molecule to its fructose and glucose moieties $(30,37)$. Paraquat action against this and other invertases would serve to stop the storage process at some point during invertase decline, and to discourage sucrose inversion relating to growth processes.

A second conclusion can be drawn relating to excessively high sucrose content of non-Paraquat treated leaf and immature storage tissues at 78 hours. Recalling the route of transport described by Hartt et al. (32), the sucrose responsible for the high immature storage tissue value must be at fraction of a greater quantity which has passed down the leaf blade, down the leaf sheath into the center of the stalk and again started down before being diverted upward in a stream moving toward the growing point. Retarded transport would not seem to be the lone factor in abnormal leaf accumulations since, within 6 hours out of darkness, comparable sucrose changes also had taken place far along the line of translocation. Some sucrose movement must therefore have begun shortly after the plants were taken from the darkroom, and we would subseribe to an unusually active degree of photosynthesis in accounting for high sucrose values in the two distinct tissues. 


\section{Enzyme Responses}

Although the same Paraquat levels were employed as in the first study, the longer duration and clearer weather conditions seemed to yield more distinct enzyme responses than were evident for experiment 1 . All of the Paraquat-induced enzyme changes underscore an essentiality of light for Paraquat action. This conclusion holds true for ATP-ase, phosphatase, amylase, peroxidase, polyphenol oxidase and invertase.

LEAF ATP-ASE AND PHOSPHATASE.-Leaf-enzyme values summarized in table 6 indicated that ATP-ase became progressively inactive in treated plants maintained in normal light. This clearly supports earlier findings with Paraquat $(14,15)$ and again implicates the adenylic acid system in Paraquat activity. However, while ATP-ase suppression was well underway by 24 hours in naturally-illuminated plants (fig. 9, A), Paraquat had no effect on ATP-ase so long as the sugarcane was kept darkened (fig. 9, B). Removal of the latter to sunlight initiated an almost immediate loss of ATP-ase activity. Thus, ATP-ase decline is a very definite part of Paraquat action and is clearly linked to light availability.

This conclusion also holds for the acid phosphatase reaction. The acid phosphatases abound in cane leaves $(1,4)$ and to measure them we use betaglycerophosphate as a suitable "catchall" substrate. ATP-ase is a distinct enzyme in cane. Nonetheless, the Paraquat and light effects noted for ATP-ase are also true of phosphatase (table 6), and from this we can surmise that organic phosphate levels in general will tend to rise in Paraquat-treated sugarcane. Increased organic phosphate in cane leaves has been demonstrated with foliar Diquat and dinitro-butylphenol (15).

An important point is the abruptness of ATP-ase and phosphatase decline upon transfer from darkness to light. This strongly suggests that Paraquat is involved in a second rate-limiting reaction which proceeds independently of light. For example, leaf ATP-ase declined by 3 percent during the first 6 hours of Paraquat action in undarkened cane. Transfer of darkened cane to sunlight yielded a 43 percent decline of ATP-ase during the first 6 hours. Thus we can conclude that the rate of Paraquat action normally observed against cane enzyme is actually limited by one or more secondary reactions. The quickness of inhibition suggests a direct action against the enzyme rather than against enzyme synthesis. If Paraquat is acting directly upon the enzyme then we would visualize gradual encounter of oxidized Paracpuat with some portion of the enzyme molecule, and subsequent formation of a non-toxic enzyme-Paraquat complex. The complex, formed in the dark, would await photoreduction of Paraquat to a not-so-free radical, the latter then instigating a rapid enzyme inhibition. If Paraquat is acting against enzyme synthesis then a comparable complex would form with some critical constituent, such as messenger-RNA, or perhaps with certain of the amino-acids making up the molecule's peptide chain. 


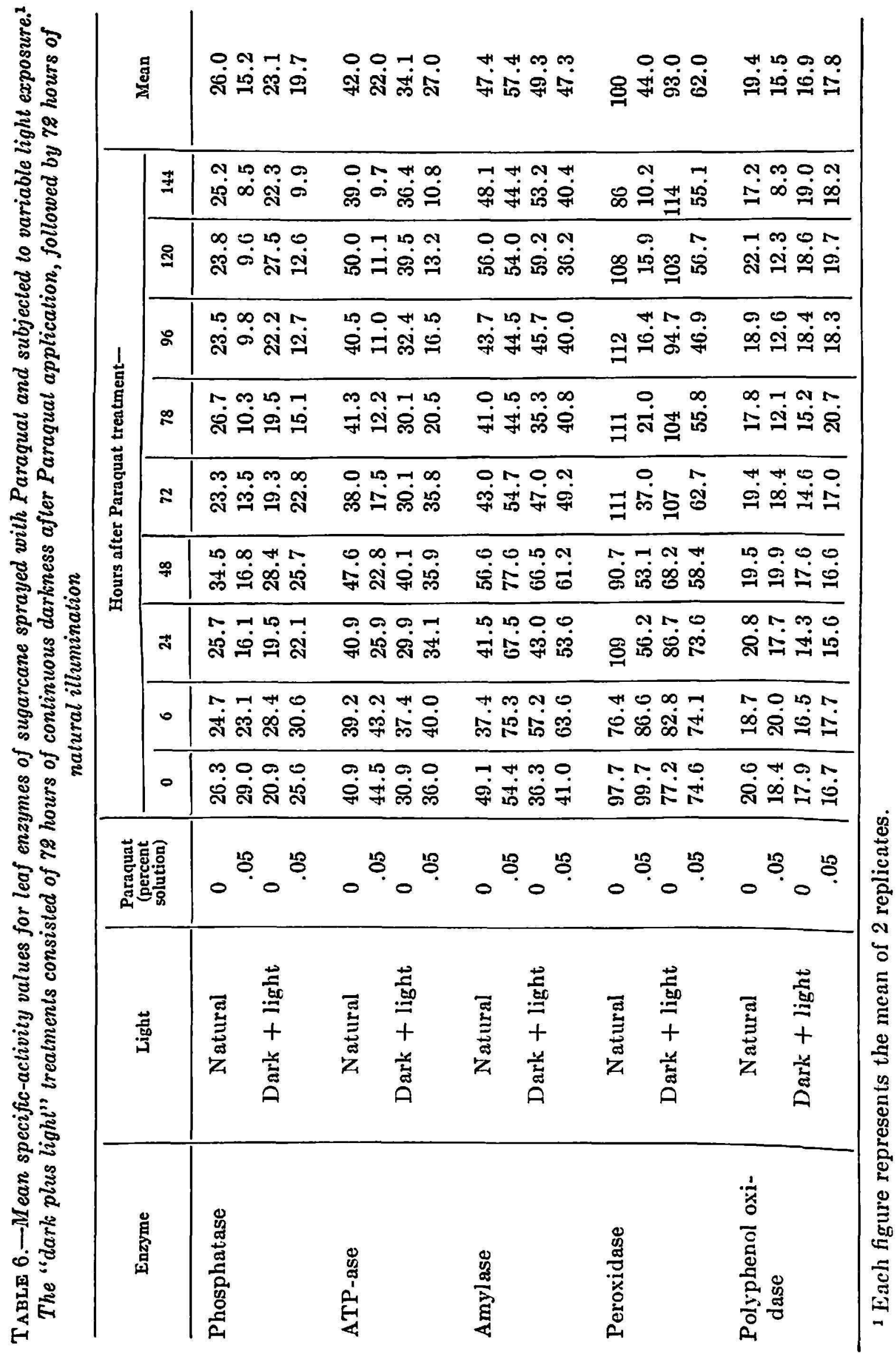


Translocation of Paraquat would not have been a rate-limiting factor for the leaf ATP-ase inhibition described above. The herbicide's transport would be a factor for non-foliar enzymes such as the acid invertases concentrated in immature storage tissues (5) or for cytochrome $\mathbf{C}$ oxidase in sugarcane roots (9). Also of importance is the plant species being treated. Boon (22) states that Diquat causes death of Vicia faba (broad bean) within a few minutes of treatment. If sugarcane were this sensitive then the present experiments would have been finished by the time our plants were carried to the darkroom.

LEAF AMYLASE.-Amylase has varied greatly in response to Paraquat and Diquat during earlier studies (14,15). Yet, more than any other enzyme,

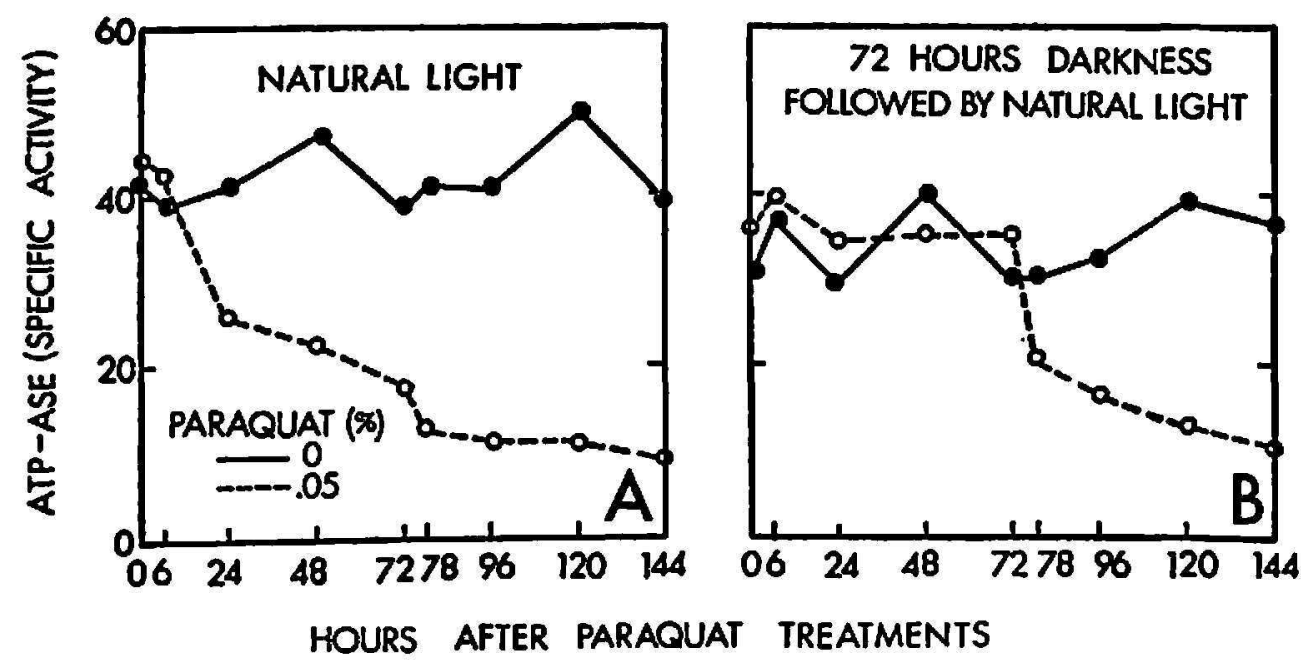

Fig. 9.-Effects of Paraquat on ATP-ase activity of sugarcane given variable light exposure: A, Enzyme decline in plants receiving natural illumination; B, retention of ATP-ase activity in darkened plants, followed by abrupt decline after reillumination.

amylase has resisted inhibitory effects and frequently has been stimulated. Amylase is regarded here as an extremely critical factor in determining the level of sucrose to be produced and retained by sugarcane $(1,3,10,11)$. Amylase is very active in carbohydrate utilization. Stimulation of this enzyme, within a carbohydrate production/utilization ratio in which production has ceased, was interpreted as a contributing factor in the sucrose losses experienced by Paraquat- and Diquat-treated plants $(14,15)$.

Leaf amylase activity was again increased by Paraquat during experiment 2 (fig. 10, A). The effect was confined to the plants receiving natural light. No appreciable stimulation occurred in darkened sugarcane (fig. 10, B). However, cane amylase, or the sequence of enzymes to which we assign the term amylase, is too complex to yield quick conclusions. Certainly it is involved in major carbohydrate shifts that we know nothing about, that outwardly lend the enzyme an appearance of instability. We can only say 
that amylase stimulation, like the retardation of phosphatase and ATP-ase, seems to require the reduced free radical of Paraquat. Unlike phosphatase and ATP-ase, there are no apparent dark reactions which permit quick activation of amylase upon reexposure to light. Any Paraquat activity toward amylase in darkness would appear to favor later inhibition rather than stimulation (fig. 10, B).

LEAF PEROXIDASE.-Within 24 hours of Paraquat treatment leaf peroxidase experienced severe activity decline, and by the close of the study only a fraction of the initial activity level was being maintained (fig. 11, A). The Paraquat effect was far less severe in plants darkened for 72 hours

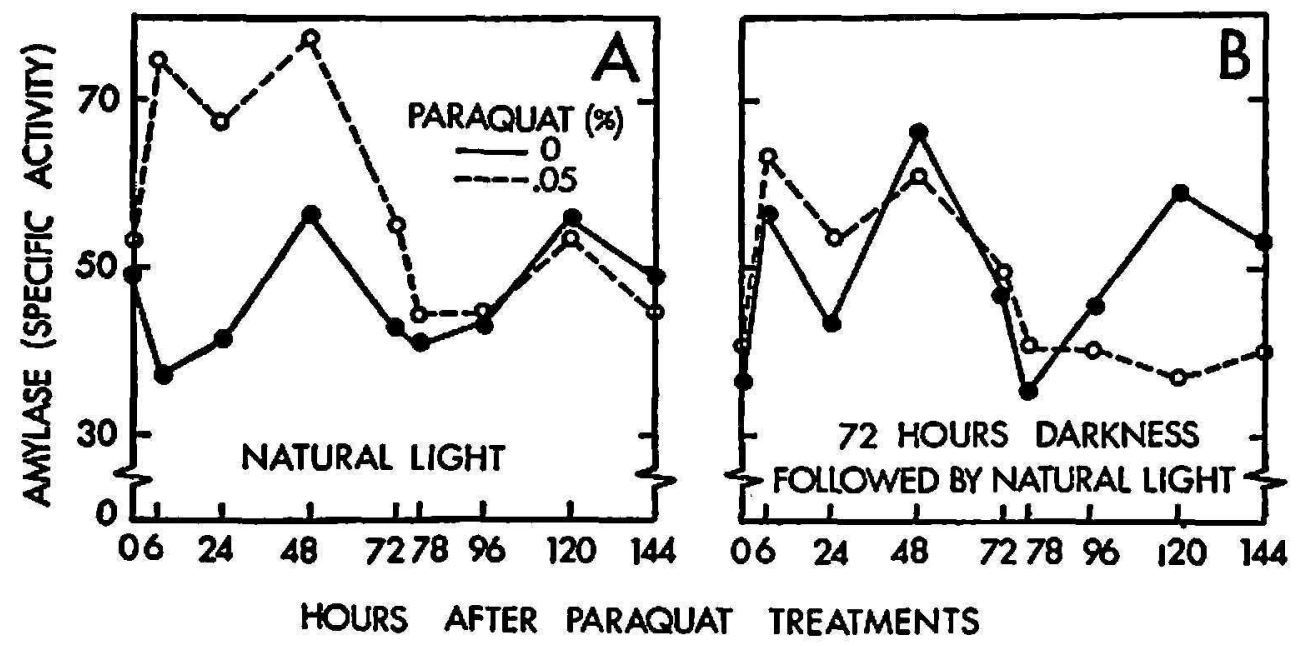

FrG. 10. -Effects of Paraquat on leaf amylase activity of sugarcane given variable light exposure; A, Early stimulation in plants receiving natural light; B, failure of Paraquat to stimulate amylase in plants given 72 hours darkness prior to natural light.

(fig. 11, B). Cane peroxidase inhibition has been reported for Paraquat and Diquat $(14,15)$.

Although peroxidase activity has sometimes been correlated with sucrose level $(1,2)$, the role of this enzyme in sugarcane has never been established (8). Hydrogen peroxide destruction has not been seriously considered here because it does not accumulate normally in plants. Boon (22), however, has proposed that peroxides play a key role in the Paraquat destruction of plant tissues, and that peroxide synthesis can follow the reoxidation of Paraquat's free radical. If this is correct, cane peroxidase might serve in a protective capacity as the Paraquat action progressed. The enzyme clearly is not able to do this under natural light because of its own inhibition.

Strong significance must be attached to the fact that peroxidase did resist Paraquat in darkened plants (fig. 11, B). This suggests that the plant will make an effort to prepare for the toxic chemical when forewarned of 
its coming. Also indicated is the likelihood of a second type of dark reaction taking place. From figure 11, B we must grant that Paraquat did suppress peroxidase even in darkened plants. But throughout the study darkened plants still retained at least 50 percent of normal activity, as compared to about 12 percent for undarkened cane. For many enzymes this could mean the difference between a plant's death and its survival.

The dark reaction suggested for peroxidase is distinct from that of ATP-ase. Paraquat seems to have entered the leaf and prepared for ATP-ase inhibition without unduly disturbing that enzyme (fig. 9). We suggested that an ATP-ase-Paraquat union had formed and awaited only the reduced radical for enzyme suppression. A Paraquat-peroxidase antagonism, though

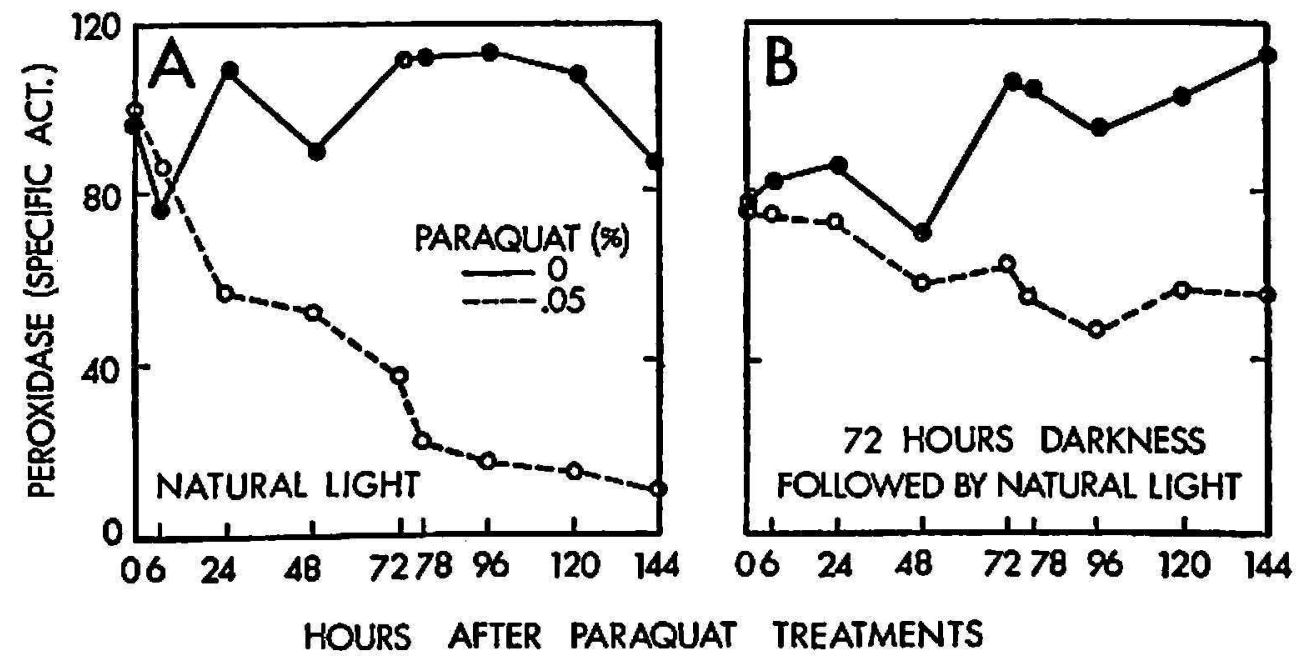

Fig: 11.-Effects of Paraquat on left peroxidase activity of sugarcane given variable illumination: A, Activity decline in plants receiving natural light; B, apparent resistance to inhibition by plants given 72 hours darkness prior to natural light.

restrained in darkness, must have triggered an "awareness" of the danger now being posed against the enzyme. The plant could have reacted by stepping up its synthesis of peroxidase. It is interesting to note that cane does have a powerful generative capacity for peroxidase. We have boiled the enzyme for 5 minutes and later observed recovery of peroxidase action (8). Gaylor and Glasziou (28) have employed peroxidase generation in incubated stem tissue slices to help measure decay of messenger-RNA. If one considers that small amounts of reduced free radical formed and led to traces of hydrogen peroxide during darkness-possibly as a result of the 4 or 5 minutes of initial light exposure, then the plant's preparation for subsequent toxic reactions is easily explained. In this case the plant would begin destroying peroxide by whatever means were available and would be active in this task when much greater amounts appeared.

LEAF POLYPHENOL OXIDABE.-Although this enzyme was not inhibited 
so severely by Paraquat as some of the others (table 6), several considerations should be noted. First, it has been reported that Paraquat inhibits respiration $(22,43)$ or stimulates it (27). Polyphenol oxidase is considered the principal terminal oxidase in aerial cane tissues (7), and hence it is a critical respiratory enzyme. Its inhibition by Paraquat was delayed until after 72 hours (fig. 12, A) and in darkened plants the enzyme was not affected at all (fig. 12, B). Therefore, it could not have been a primary factor in the desiccant's critical action. A similar delay for the Paraquatoxidase relationship was recorded earlier (14), as was the need for relatively high chemical levels to accomplish inhibition.

Apparently the inhibition of polyphenol oxidase is related to water

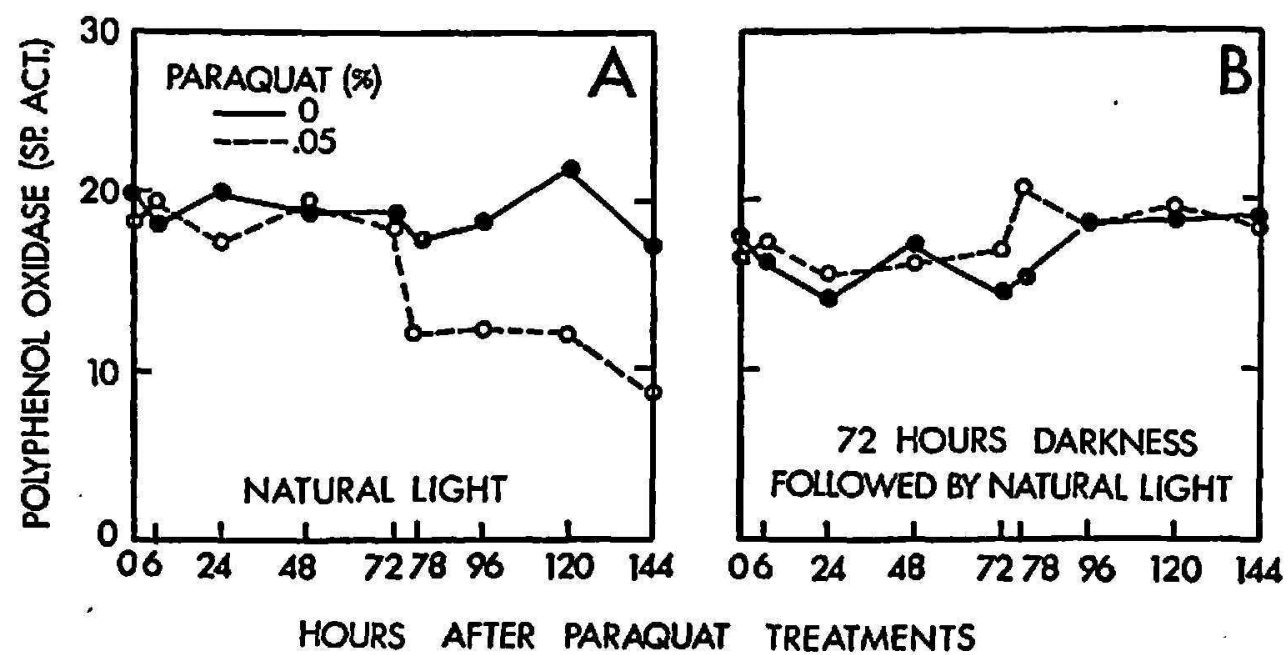

FiG. 12.-Effects of Paraquat on leaf polyphenol oxidase activity of sugarcane given variable light exposure: A, Delayed inhibition of the enzyme, beginning between 72 and 78 hours; $B$, removal of inhibitory action in plants given 72 hours darkness prior to natural light.

stress rather than to any peculiar property of Paraquat. It is true that light was required for the enzyme to be retarded, but again light was required for desiccation. This enzyme seems to demonstrate that not all catalysts or enzyme-producing mechanisms are directly vulnerable to Paraquat.

INVERTASe.-Both light and Paraquat revealed powerful effects on the cane invertase extracted from immature storage tissues (table 7, fig. 13). The enzyme literally summarizes in itself most of the Paraquat-light relationships discussed in this paper. Both the absence of light and the presence of Paraquat caused severe invertase decline. The decline curves are identical. This suggests that for invertase, like sucrose synthesis, the application of Paraquat is about comparable to beginning a continuous night. Removal of non-treated plants to sunlight leads to invertase recovery; those treated with Paraquat do not recover activity. Since 
TABLE 7.-Mean specific-activity values for immature slorage tissue enzymes of sugarcane sprayed with Paraquat and subjected to variable light exposure ${ }^{1}$

\begin{tabular}{|c|c|c|c|c|c|c|c|c|c|c|c|}
\hline \multirow{3}{*}{ Enzyme } & \multirow{3}{*}{$\begin{array}{c}\text { Paraquat } \\
\text { (percent } \\
\text { solution) }\end{array}$} & \multicolumn{9}{|c|}{ Hours after Paraquat treatment- } & \multirow{3}{*}{ Mean } \\
\hline & & \multicolumn{5}{|c|}{ In total darkness } & \multicolumn{4}{|c|}{ In normal light } & \\
\hline & & 0 & 6 & 24 & 48 & 72 & 78 & 96 & 120 & 144 & \\
\hline Phosphatase & $\begin{array}{l}0 \\
\quad .05\end{array}$ & $\begin{array}{l}22.4 \\
22.6\end{array}$ & $\begin{array}{l}24.8 \\
25.1\end{array}$ & $\begin{array}{l}20.7 \\
22.6\end{array}$ & $\begin{array}{l}29.7 \\
25.2\end{array}$ & $\begin{array}{l}22.7 \\
21.3\end{array}$ & $\begin{array}{l}19.6 \\
18.9\end{array}$ & $\begin{array}{l}24.0 \\
14.8\end{array}$ & $\begin{array}{l}32.3 \\
17.8\end{array}$ & $\begin{array}{l}39.9 \\
23.7\end{array}$ & $\begin{array}{l}26.2 \\
21.3\end{array}$ \\
\hline ATP-ase & $\begin{array}{l}0 \\
\quad .05\end{array}$ & $\begin{array}{l}22.1 \\
22.4\end{array}$ & $\begin{array}{l}25.1 \\
24.1\end{array}$ & $\begin{array}{l}18.0 \\
22.6\end{array}$ & $\begin{array}{l}27.9 \\
25.6\end{array}$ & $\begin{array}{l}23.4 \\
21.6\end{array}$ & $\begin{array}{l}20.2 \\
18.5\end{array}$ & $\begin{array}{l}23.1 \\
16.8\end{array}$ & $\begin{array}{l}31.9 \\
18.2\end{array}$ & $\begin{array}{l}36.2 \\
23.8\end{array}$ & $\begin{array}{l}25.3 \\
21.5\end{array}$ \\
\hline Amylase & $\begin{array}{l}{ }^{0} \\
.05\end{array}$ & $\begin{array}{l}51.4 \\
52.2\end{array}$ & $\begin{array}{l}55.6 \\
50.4\end{array}$ & $\begin{array}{l}54.5 \\
62.4\end{array}$ & $\begin{array}{l}89.8 \\
80.6\end{array}$ & $\begin{array}{l}80.1 \\
65.4\end{array}$ & $\begin{array}{l}78.6 \\
73.8\end{array}$ & $\begin{array}{l}88.0 \\
58.8\end{array}$ & $\begin{array}{l}78.5 \\
66.2\end{array}$ & $\begin{array}{l}77.3 \\
81.1\end{array}$ & $\begin{array}{l}72.6 \\
65.6\end{array}$ \\
\hline Invertase & $\begin{array}{l}0 \\
.05\end{array}$ & $\begin{array}{l}17.5 \\
15.8\end{array}$ & $\begin{array}{l}4.9 \\
5.8\end{array}$ & $\begin{array}{l}4.1 \\
5.1\end{array}$ & $\begin{array}{l}0.6 \\
0.4\end{array}$ & $\begin{array}{l}0.5 \\
1.5\end{array}$ & $\begin{array}{l}1.7 \\
0.3\end{array}$ & $\begin{array}{r}12.5 \\
1.6\end{array}$ & $\begin{array}{r}17.3 \\
2.0\end{array}$ & $\begin{array}{r}29.5 \\
0.8\end{array}$ & $\begin{array}{l}9.8 \\
3.7\end{array}$ \\
\hline Peroxidase & $\begin{array}{l}0 \\
.05\end{array}$ & $\begin{array}{l}34.7 \\
34.4\end{array}$ & $\begin{array}{l}27.6 \\
36.4\end{array}$ & $\begin{array}{l}25.7 \\
30.6\end{array}$ & $\begin{array}{l}37.1 \\
33.1\end{array}$ & $\begin{array}{l}23.9 \\
27.2\end{array}$ & $\begin{array}{l}21.4 \\
27.1\end{array}$ & $\begin{array}{l}37.0 \\
22.1\end{array}$ & $\begin{array}{l}42.4 \\
28.0\end{array}$ & $\begin{array}{l}44.1 \\
41.8\end{array}$ & $\begin{array}{l}32.7 \\
31.2\end{array}$ \\
\hline Polyphenol oxidase & $\begin{array}{l}0 \\
.05\end{array}$ & $\begin{array}{l}13.3 \\
17.4\end{array}$ & $\begin{array}{l}15.1 \\
13.8\end{array}$ & $\begin{array}{l}13.3 \\
12.8\end{array}$ & $\begin{array}{l}17.2 \\
14.7\end{array}$ & $\begin{array}{l}11.9 \\
12.7\end{array}$ & $\begin{array}{l}11.0 \\
11.1\end{array}$ & $\begin{array}{l}18.0 \\
10.8\end{array}$ & $\begin{array}{l}18.5 \\
11.9\end{array}$ & $\begin{array}{l}21.5 \\
16.3\end{array}$ & $\begin{array}{l}15.5 \\
13.5\end{array}$ \\
\hline
\end{tabular}

1 Each figure represents the mean of 2 replicates. 
growth has been closely correlated with invertase activity in several plant species $(36,40,50)$, it is possible that invertase inhibition plays a role in Paraquat suppression of cane tonnage (18).

The recovery of invertase in light was not especially rapid (fig. 13); it took about as long to recover full activity as was needed to lose it. In the instance of invertase it appears that a light-requiring mechanism of synthesis is acted upon both by Paraquat and darkness. The mechanism is viable in the absence of light, but some constituent is apparently destroyed by Paraquat upon reintroduction of the cane to sunlight. There is evidence that, without Paraquat, the invertase lost will be more than adequately replaced over a period of several days. The overcompensation illustrated

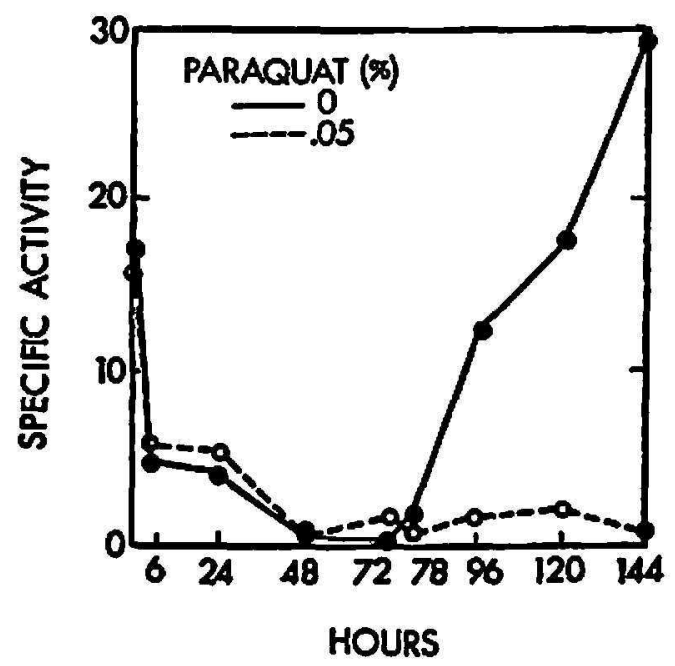

Fra. 13.-Effects of Paraquat on invertase from immature storage tissue of sugarcane given variable light exposure. Illustrated in the invertase decline as a response to darkness and Paraquat. After reillumination, there is complete invertase recovery in Paraquat-free plants, while invertase fails to recover in plants sprayed with the herbicide.

in figure 13 supports the contention that invertase synthesis rather than invertase reactivation is involved.

\section{SUMMARY}

Light relationships to enzyme and sugar transformations were studied in sugarcane treated with Paraquat. A bipyridylium herbicide, Paraquat has shown promise as a preharvest-desiccant and flower-controlling agent, but causes undesirable sugar and growth restrictions. The present studies were conducted as part of a program having chemical control of sucrose as an ultimate purpose. There were three objectives: 1 , To clarify the dependence of Paraquat on light for its desiccative action; 2 , to clarify the roles of light in abnormal enzyme behavior induced by Paraquat; and 3, to define the role of light in sucrose losses triggered by Paraquat. 
Two experiments were conducted with immature sugarcane of the variety P.R. 980. All plants were grown by sand culture in the greenhouse under strict water and nutritional control. For the first experiment plants were treated with 0 or 0.05 percent Paraquat solutions and subjected to continuous darkness or maintained under natural illumination. During the second experiment one group of plants was darkened for 72 hours followed by 72 hours of natural illumination, and a second group was maintained for 144 hours with natural light exposure. During both studies leaf and immature storage tissues were frozen at appropriate intervals for enzyme and sugar analyses. Enzymes assayed included acid phosphatase, ATP-ase, amylase, invertase, peroxidase and polyphenol oxidase. Changes in sucrose, fructose, glucose and ribose were studied by paper chromatography.

The following results were obtained:

1. Darkened cane did not experience typical Paraquat destruction of green tops as did those kept under normal light. Leaf sucrose declined markedly among all darkened plants. Nearly identical sucrose losses were recorded in Paraquat-treated plants receiving normal illumination.

2. Regarding sucrose synthesis, it was concluded that Paraquat treatment of sugarcane has an effect equivalent to a continuous night of several weeks or more duration.

3. During the first experiment ATP-ase was greatly suppressed by Paraquat under normal light conditions. The herbicide's effect was blocked by darkness. The involvement of Paraquat in the adenylic acid system and its consequences is discussed. Invertase was suppressed both by darkness and by Paraquat.

4. During experiment 2, undarkened plants experienced severe foliar drying within 72 hours after Paraquat treatment. At this time the darkened plants still appeared green and normal. Removal to sunlight initiated typical foliar destruction by the herbicide.

5. Plants not treated with Paraquat lost sucrose and reducing sugars in darkness, but the sugars reappeared when plants were reintroduced to light. The 0.05 percent Paraquat level caused typically severe sucrose decline. Sucrose did not recover under natural illumination nor in darkened plants upon reexposure to light.

6. During both experiments, Paraquat-treated plants accumulated ribose in their leaves, indicating a blockage of photosynthesis at the site of phosphoribose isomerase action, i.e., in the conversion of ribose-5-phosphate to ribulose-5-phosphate.

7. In spite of continuing ribose production, reexposure of darkened, Paraquat-treated plants to sunlight led to recovery of fructose and glucose production. It is suggested that an alternate method of ribulose-5- 
phosphate formation, from xylulose-5-phosphate, and catalyzed by ribulose phosphate-xylulose phosphate isomerase, was activated during darkness. This presupposes that a dark reaction occurs in which foliar mechanisms are sensitized to danger before the herbicide assumes phytotoxic capability.

8. Failure of leaf sucrose to recover after reexposure to sunlight suggests that Paraquat is also acting against sucrose synthetase or related catalysts of sucrose biosynthesis.

9. Darkened, herbicide-free cane accumulated excessive amounts of sucrose in leaf and immature storage tissues within 6 hours after reillumination. The possibility of effecting more efficient sucrose production by stress of darkness, as opposed to limitations of sugar transport, are discussed.

10. The leaf enzymes ATP-ase, acid phosphatase, amylase, peroxidase, and polyphenol oxidase, plus invertase from immature storage tissue, were all significantly altered by light or Paraquat treatments during experiment 2.

$A T P$-ase: The enzyme was severely suppressed by Paraquat in light, but not in darkness, and was rapidly suppressed upon reexposure to light. Evidence is presented of a non-toxic dark reaction which disposes of steps normally rate-limiting in daylight. Similar effects were noted upon acid phosphatase.

Amylase: Amylase was stimulated by Paraquat in light which verified earlier findings. Amylase is considered a major factor in the herbicide's stimulation of metabolic processes. Darkness eliminated the stimulatory effect. A Paraquat free-radical produced after darkness may not be identical to that formed upon immediate exposure to light.

Peroxidase: This enzyme declined sharply in illuminated plants given Paraquat. Darkened plants strongly resisted the Paraquat suppression, although some loss of activity still occurred. It is suggested that traces of peroxide were formed and "alerted" peroxide-destroying mechanisms. Such an alarm system would be distinct from the darkened Paraquat-ATPase relationship in which the plant apparently made no effort to save an endangered enzyme.

Polyphenol oxidase: Moderate Paraquat inhibition took place in light; none occurred in darkness or following darkness. Inhibition was delayed for about 3 days. An indirect Paraquat effect such as increasing moisture stress is suspected.

Invertase: The enzyme's activity pattern was vastly altered by light and Paraquat. Darkness and Paraquat suppressed invertase with identical decline curves. Reillumination led to full invertase recovery plus significant overcompensation in zero-Paraquat plants. No recovery occurred in cane given Paraquat. A light-sensitive mechanism of invertase synthesis is proposed, with darkness and Paraquat giving reversible and non-reversible inhibition, respectively. 
11. Sugarcane growth, sugar, and enzyme data concur with the supposition that a free radical of Paraquat is produced by photoreduction. In addition, prior to reduction and reoxidative transformations, there appears to be several types of herbicide-enzyme reactions occurring independently of light. These include: 1, Disposal of secondary but rate-limiting steps which speed an ultimate enzyme inhibition in light; and 2, sensitizing reactions in which critical enzymes are forewarned of phytotoxic compounds and essentially defensive or protective mechanisms are alerted.

\section{RESUMEN}

Se estudiaron las relaciones entre la luz y las enzimas y las transformaciones del azúcar en caña de azúcar tratada con Paraquat. El Paraquat es un herbicida de dipiridilio, que promete actuar como desecante si se aplica antes de la recolección y como agente regulador de la floración, aunque causa limitaciones indeseables en la formación del azúcar y en el crecimiento. Estos estudios se llevaron a cabo como parte de un programa, cuyo propósito esencial es el control químico de la sacarosa. Eran tres los objetivos: 1, Esclarecer de qué modo depende el Paraquat de la luz para su acción desecante; 2 , aclarar la función de la luz en el comportamiento enzimático anormal inducido por el Paraquat; y 3, definir el papel que desempeña la luz en las pérdidas de sacarosa iniciadas por el Paraquat.

Se llevaron a cabo dos experimentos con caña de azúcar inmatura de la variedad P.R. 980. Todas las plantas se cultivaron en arena en un invernadero bajo estricto control de agua y nutrimentos. En el primer experimento, las plantas se trataron con soluciones al 06 al 0.05 por ciento de Paraquat, Unas se sometieron a oscuridad continua y otras permanecieron bajo iluminación natural. En el segundo experimento, un grupo de plantas permaneció a oscuras durante 72 horas y luego se expusieron a la luz natural durante 72 horas; un segundo grupo se mantuvo expuesto a la luz natural durante 144 horas. En ambos estudios, los tejidos foliar y reservante tierno se congelaron a intervalos apropiados para hacer un análisis de las enzimas y el azúcar. Los análisis incluyeron fosfatasa ácida, ATP-asa, amilasa, invertasa, peroxidasa y oxidasa de polifenol. Los cambios en la sacarosa, fructosa, glucosa y ribosa se estudiaron mediante la cromatografía sobre papel.

Se lograron los siguientes resultados:

1. En la oscuridad, las plantas no experimentaron la destrucción del cogollo verde, típica del Paraquat, tal como ocurrio con las que permanecieron bajo luz natural. La sacarosa foliar bajó marcadamente en todas las plantas expuestas a la oscuridad. Se registraron pérdidas casi idénticas de sacarosa en aquellas plantas tratadas con Paraquat y que se sometieron a iluminación normal.

2. Con respecto a la síntesis de la sacarosa, se concluyó que el tratamiento 
de la caña de azúcar con Paraquat tiene un efecto equivalente a una noche continua de varias semanas o más de duración.

3. En el primer experimento, la ATP-asa fue severamente inactivade por el Paraquat bajo condiciones normales de luz. El efecto del herbicida fue bloqueado por la oscuridad. Se discute la participación del Paraquat y sus consecuencias en el sistema de ácido adenílico. La invertasa fue inactivada, tanto por la oscuridad como por el Paraquat.

4. En el segundo experimento, las plantas que no se expusieron a las oscuridad sufrieron una severa desecación foliar dentro de las 72 horas posteriores al tratamiento con Paraquat, mientras que en ese mismo periodo las plantas mantenidas a oscuras todavía continuaban verdes y normales. Al exponerlas a la luz solar se inició la destrucción foliar típica del herbicida.

5. Las plantas no tratadas con el Paraquat perdieron sacarosa y azúcares reductores en la oscuridad, pero los azúcares reaparecieron cuando las plantas se expusieron nuevamente a la luz. Una concentración de 0.05 por ciento de Paraquat causó un descenso severo de sacarosa. La sacarosa no recuperó su nivel bajo la iluminación natural, ni en las plantas sombreadas expuestas nuevamente a la luz.

6. En ambos experimentos, las plantas tratadas con Paraquat acumularon ribosa en las hojas, indicando así un bloqueo de la fotosíntesis en la etapa de la acción de la isomerasa de fosforribosa, es decir, al convertirse la ribosa-5-fosfato a ribulosa -5-fosfato.

7. A pesar de una continua producción de ribosa, el exponer de nuevo las plantas que habían sido expuestas a la oscuridad y tratadas con Paraquat á la luz solar, indujo una recuperación de fructosa y producción de glucosa. Se sugiere un método alterno mediante el cual la xilulosa-5-fosfato, catalizada por la isomerasa de ribulosa fosfato-xilulosa fostato, se activa en la oscuridad para dar lugar a ribulosa-5-fosfato. Esto presupone que ocurre una reacción causada por el efecto de la oscuridad en la que mecanismos foliares se tornan sensibles al peligro antes de que el herbicida alcance una capacidad fitotóxica.

8. El hecho de que la sacarosa foliar no recupere después de exponerse de nuevo a la luz solar, sugiere que el Paraquat actúa también contra la sintetasa de la sacarosa o los catalizadores relacionados con la biosíntesis de la sacarosa.

9. La caña expuesta a la oscuridad y libre de herbicida acumuló cantidades excesivas de sacarosa en la hoja y en el tejido reservante tierno dentro de las 6 horas después de la reiluminación. Se discute la posibilidad de efectuar una producción más eficiente de sacarosa mediante la influencia de la oscuridad, en oposición a las limitaciones en el transporte del azúcar.

10. Las enzimas foliares como la ATP-asa, fosfatasa ácida, amilasa, 
peroxidasa y oxidasa de polifenol, más la invertasa del tejido reservante tierno, fueron significativamente alteradas por el tratamiento con luz o con Paraquat, en el segundo experimento.

ATP-asa: Esta enzima fue inactivada severamente por el Paraquat bajo la luz, mas no en la oscuridad, y también lo fue rópidamente al exponerse de nuevo a aquélla. Se comprueba la presencia de una reacción no tóxica que ocurre por efecto de la oscuridad, la cual elimina los pasos que normalmente limitan su intensidad, al exponerse a la luz natural. Se notaron efectos similares en la fosfatasa ácida.

Amilasa: Esta enzima fue estimulada por el Paraquat en presencia de la luz, lo que comprobo los hallazgos anteriores. Se estima que la amilasa es un factor principal en la acción estimulante de los procesos metabólicos del herbicida. La oscuridad eliminó el efecto estimulante. Una radical libre del Paraquat, producida después de la exposición a la oscuridad, podría no ser idéntica a la formada por la exposición inmediata a la luz.

Peroxidasa: Esta enzima disminuyó agudamente en las plantas iluminadas que se trataron con Paraquat. Las plantas a oscuras resistieron fuertemente la inactivación causada por el Paraquat, aunque aún así hubo alguna pérdida en actividad. Se sugiere la formación de trazas de peróxido que excitaron a los mecanismos destructores del peróxido. Tal sistema de alarma podría ser distinto a la relación entre el Paraquat a oscuras y la ATP-asa, en la que la planta no hizo esfuerzos por proteger la enzima puesta en peligro.

Oxidasa de polifenol: Una inhibición moderada del Paraquat tuvo lugar bajo la luz; sin embargo, no ocurrió ninguna durante o después de ser expuesta a la oscuridad. La inhibición se retrasó cerca de 3 días. Se sospecha la presencia de un efecto indirecto del Paraquat, tal como cierta intensidad en la limitación de la humedad.

Invertasa: El patrón de actividad enzimática de la invertasa se alteró marcadamente debido a la luz y al Paraquat. La oscuridad y el Paraquat deprimieron la invertasa con curvas idénticas de declinación. La reiluminación indujo una recuperación completa de la invertasa más una sobrecompensación en las plantas que no se trataron con el Paraquat. No hubo tal recuperación en las plantas tratadas con el Paraquat. Se propone que un mecanismo sensitivo a la luz interviene en la sintesis de la invertasa, y que la oscuridad y el Paraquat inducen una inhibición reversible e irreversible, respectivamente.

11. Los datos sobre el crecimiento, el azúcar y las enzimas concuerdan con la suposición de que la fotorreducción da paso a una radical libre del Paraquat. Además, antes de que las transformaciones reductoras y reoxidantes ocurran, parece que varias reacciones de tipo herbicida-enzima tienen lugar, independientemente de la luz. Estas incluyen: 1, Pasar por 
alto los pasos secundarios que retardan la reacción, lo que acelera la inhibición de una enzima esencial al exponerse a la luz; y 2, reacciones sensibilizadoras en las que a las enzimas decisivas se les previene de compuestos fitotóxicos y se alertan los mecanismos esencialmente defensivos o protectores.

\section{LITERATURE CITED}

1. Alexander, A. G., Sucrose-enzyme relationships in immature sugarcane as affected by varying levels of nitrate and potassium supplied in sand culture, $J$. Agr. Univ. P.R. 48 (3): 165-231, 1964.

2. - Changes in leaf sugar content asd enzyme activity of immature sugarcane following foliar application of indole-3-acetic acid, 2,4-dichlorophenoxyacetic acid, and maleic hydrazide, J. Agr. Univ. P.R. 49 (1): 1-34, 1965.

3. - Physiological studies of enzymes catalyzing the synthesis and hydrolysis of sucrose, starch, and phosphorylated hexose in sugarcane, J. Agr. Univ. P.R. 49 (1): 60-75, 1965.

4. - Hydrolytic proteins of sugarcane: The acid phosphatases, J. Agr. Univ. P.R. 49 (2): 204-28, 1965 .

5. - Hydrolytic proteins of sugarcane: The acid invertases, J. Agr. Univ. P.R. 48 (3): 207-30, 1965.

6. - Hydrolytic proteins of sugarcane : Amylase, J. Agr. Univ. P.R. 49 (3): 308-24, 1965.

7. - Oxidizing enzymes of sugarcane: Tyrosinase, J. Agr. Univ. P.R. 60 (2): 113-30, 1966.

8. - Oxidizing enzymes of sugarcane: Peroxidase, J. Agr. Univ. P.R. 60 (1): 36-52, 1966.

9. - Oxidizing enzymes of sugarcane: Cytochrome C oxidase, J. Agr. Univ. P.R. 60 (2): 131-45, 1966.

10. - High sucrose content and abnormal enzyme activity as a function of nutritional stress in sugarcane, J. Agr. Univ. P.R. 51 (4): 325-33, 1967.

11. Alexander, A. G., and Samuels, G., Controlled-temperature studies of growth, enzymology and sucrose production by two sugarcane varieties in Puerto Rico, J. Agr. Univ. P.R. 62 (3): 204-17, 1968.

12. Alexander, A. G., In vitro effects of silicon on hydrolytic and oxidative enzymes of sugarcane, Proc. XIII Cong. Int. Soc. Sugar Cane Technol. 1968, Preprint no. A-08.

13. - The potential of sugarcane to produce sucrose, Proc. XIII Cong. Int. Soc. Sugar Cane Technol. Taiwan, 1968, Preprint no. S-29.

14. Alexander, A. G., and Montalvo-Zapata, R., Enzyme studies of sucrose decline in sugarcane desiccated with Paraquat, J. Agr. Univ. P.R. 58 (4): 230-50, 1969.

15. - and - Enzymatic factors in the sucrose decline of sugarcane desiccated with Paraquat, Diquat, and Dinitrobutylphenol, J. Agr. Univ. P.R. 64 (1): $28-491970$.

16. - and - The use of silicon to preserve sucrose in sugarcane desiccated with Paraquat and Diquat, J. Agr. Univ. P.R. 54 (2): pp. 247-63, 1970.

17. Alexander, A. G., Montalvo-Zapata, R., and Kumar, A., Enzyme-silicon studies of gibberellic acid-treated sugarcane during the post growth-stimulatory phase, J. Agr. Univ. P.R. 54 (1): 82-95 1970.|

18. Alexander, A. G., Montalvo-Zapata, R., and Spain, G. L., Prevention of sugarcane flower production with Paraquat, gibberellic acid and silicon: Chemical 
effects on growth, sucrose production and enzyme activity, J. Agr. Univ. P.R. in press

19. Axelrod, B., and Jang, R., Purification of phosphoriboisomerase from alfalfa, J. Biol. Chem. 209: 847-55, 1954.

20. Bassham, J. A., Photosynthesis: The path of carbon; Chap. 34, in: Bonner, J. and Varner, J. E., Plant Biochemistry, Academic Press, New York, N.Y., 1865.

21. Bates, J. F., Preliminary trials with desiccants in sugarcane, Proc. Br. W. Ind. Sug. Technol. 43-8, 1960.

22. Boon, W. R., The chemistry and mode of action of the bipyridylium herbicides 4 Diquat and Paraquat, FOCUS. A Plant Protection information service, Plant A Protection Limited, Fernhurst, Haslemere, Surrey, England, 1968.

23. Cardini, C. E., Leloir, L. F., and Chiriboga, J., The biosynthesis of sucrose, J. Biol. Chem. 214: 149-55, 1955.

24. Davenport, M. E., Summary of research. Plant biochemistry, Ann. Rept. Long Ashton Res. Sta. p. 32, 1960.

25. Davidson, L. G., Effects of desiccants on sugarcane, Proc. Int. Soc. Sugar Cane Technol. 11: 319-23, 1962.

26. Dube, S. K., and Nordin, P., Isolation and properties of sorghum alpha-amylase, Arch. Biochem. and Biophys. 94: 121-7, 1961.

27. Funderburk, H. H., and Lawrence, J. M., Mode of action and metabolism of Diquat and Paraquat, Weeds 11: 259-64, 1963.

28. Gayler, K. R., and Glasziou, K. T., Plant enzyme synthesis: Decay of messenger RNA for peroxidase in sugarcane stem tissue, Phytochemistry 7: 1247-51, 1968.

29. Glasziou, K. T., Accumulation and transformation of sugars in sugar cane stalks; Plant Physiol. 35 (6): 895-901, 1960.

30. Glasziou, K. T., Waldron, J. C., and Bull, T. A., Control of invertase biosynthesis in sugarcane. Loci of auxin and glucose effects, Plant Physiol. 41: 282-88, 1966.

31. Gosnell, J. M., and Thompson, G. D., The effects of Paraquat on the growth and yield of sugarcane, Proc. Int. Soc. Sugar Cane Technol. 18: 498-500, 1968.

32. Hartt, C. E., Kortschak, H. P., Forbes, A. J., and Burr, G. O., Translocation of C14 in sugarcane, Plant Physiol. 98 (3): 305-18, 1963.

33. -,,-- , and - Effects of defoliation, deradication, and darkening the blade upon translocation of $\mathrm{C}^{14}$ in sugarcane, Plant Physiol. 89 (1): 16-22, 1964.

34. Hartt, C. E., Translocation as a factor in photosynthesis, Naturwissenschaften 21: 666-7, 1963.

35. - E Effect of moisture supply upon translocation and storage of $\mathrm{C}^{14}$ in sugarcane, Plant Physiol. 48 (3): 338-46, 1967.

36. Hatch, M. D., and Glasziou, K. T., Sugar accumulation cycle in sugar cane. II. Relationship of invertase activity to sugar content and growth rate in storage tissue of plants grown in controlled environments, Plant Physiol. 88: 344-8, 1963.

37. - Sugar accumulation cycle in sugarcane. I. Studies on enzymes of the cycle, Plant Physiol. 98 (3): 338-43, 1963.

38. Hill, R., and Walker, D. A., Pyocyanine and phosphorylation with chloroplasts, Plant Physiol. 84: 240-5, 1959.

39. Jagendorf, A. T., and Avron, M., Cofactore and rates of photosynthetic phosphorylation by spinach chloroplasts, $J$. Biol. Chem. 281: 277-89, 1958.

40. Kaufman, P. B., Ghosheh, N., and Ikuma, H., Promotion of growth and invertase activity by gibberellic acid in developing Avena internodes, Plant Physiol. 48: 29-34, 1868. 
41. Loomis, W. E., in: Photosynthesis in Plants. Iowa State Press, Ames, Iowa, p. 12, 1949.

42. Maretski, A., and Alexander, A. G., Gel filtration studies of invertase from sugarcane meristem, Enzymologia $\$ 8$ (5): 229-307, 1967.

43. Mees, G. C., Experiments on the herbicidal action of 1,1'-Ethylene-2,2'-Dipyridylium Dibromide, Ann. Appl. Biol. 48: 601-12, 1960.

44. Michaelis, L., and Hill, E. S., The viologen indicators, J. Amer. Chem. Soc. 56: 1481-94, 1933.

45. Pressey, R., Invertase inhibitors from red beet, sugar beet, and sweet potato roots, Plant Physiol. 43: 1430-34, 1968.

46. - Invertase inhibitor from potatoes: Purification, characterization, and reactivity with plant invertases, Plant Physiol. 48: 1780-86, 1967.

47. Robson, J. W., and Procter, G. C., Paraquat as a herbicide and desiccant in tropical agriculture, World Crops 15 (6): 264, 1963.

48. Roe, J. R., A colorimetric method for the determination of fructose in blood and urine, J. Biol. Chem. 107: 15-22, 1934.

49. Sacher, J. A., Hatch, M. D., and Glasziou, K. T., Regulation of invertase synthesis in sugarcane by an auxin- and sugar-mediated control system, Physiol. Plantarum 16: 836-42, 1963.

50. Seitz, K., and Lang, A., Invertase activity and cell growth in lentil epicotyls, Plant Physiol. 48: 1075-82, 1968.

51. Shropshire, W., and Bergman, K., Light induced concentration changes of ATP from Phycomyces sporangiophores: A re-examination, Plant Physiol. 48: 1317-8, 1968.

52. Slack, C. R., The physiology of sugarcane. VIII. Diurnal fluctuations in the activity of soluble invertase in elongating internodes, Aust. J. Biol. Sci. 18: 781-8, 1965.

53. Srere, P. A., Cooper, J. R., Klybas, V., and Racker, E., Xylulose-5-phosphate, a new intermediate in the pentose phosphate cycle, Arch. Biochem. Biophys. 69: 535-8, 1955.

54. Sumner, J. B., Dinitrosalicylic: A reagent for the estimation of sugar in normal and diabetic urine, J. Biol. Chem. 47: 5-9, 1926.

55. Sutherland, E. W., Cori, C. F., Haynes, R., and Olsen, N. S., Purification of the hyperglycemic-glycogenolytic factor from insulin and from gastric mucosa, J. Biol. Chem. 180: 825-37, 1949. 